\title{
OS EFEITOS DA GRANULOMETRIA DO MILHO E FORMAS DE RAÇÃo NO DESEMPENHO DE FRANGOS DE CORTE
}

\author{
MARLY KLINGER - CARDOSO
}

Engenheiro Agrânomo

Orientador : Prof. Dr. ROBERTO DIAS DE MORAES E SILVA

Dissertaçao apresentada à Escola Superior de Agricultura "Luiz de Queiroz", da Universidade de Sao Paulo, para obtença do titulo de Mestre em Agronomia, Area de concentraçă : Nutriçăo Animal e Pastagens.

PIRACICABA

Estado de Sao Paulo - Brasil

Setembro - 1990 


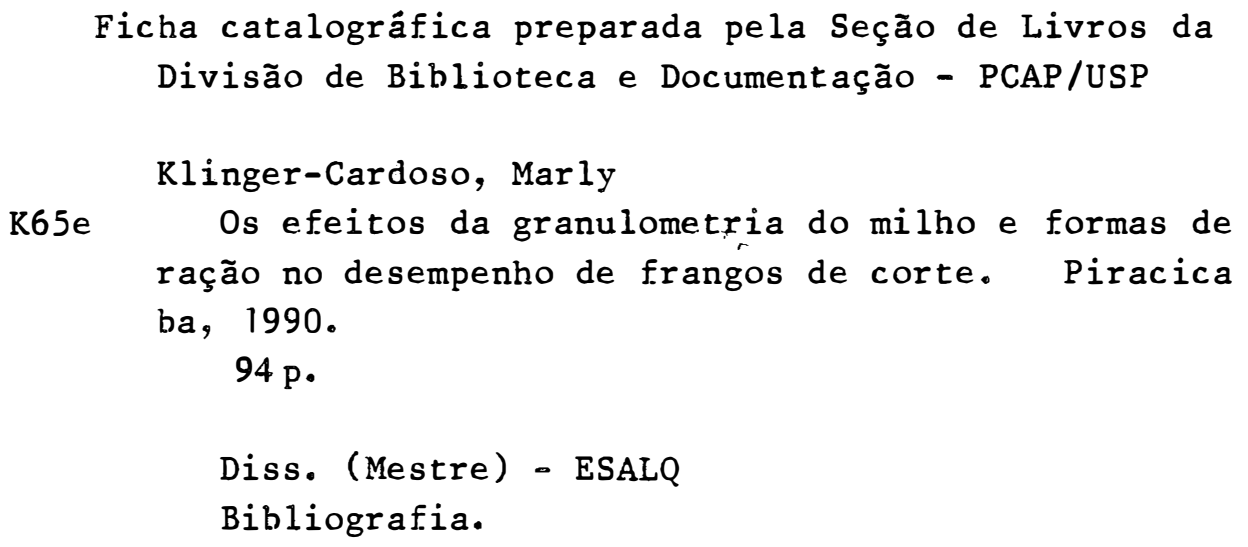
lometria do milho 2. Ração para frango de corte I. ES cola Superior de Agricultura Luiz de Queiroz, Piracicaba

CDD 536.513 


\title{
QS EFEITOS DA GRANULQMETRIA DO MILHO E FORMAS DE RAÇÃO NO DESEMPENHO DE FRANGQS DE CORTE
}

\author{
MARLY KLINGER - CARDOSO
}

Aprovada em: $19 \cdot 10 \cdot 1990$

Comissao Julgadora:

Prof. Dr. Roberto Dias de Moraes e Silva ESALQ/USP Prof. Dr. José Fernando Machado Menten ESALQ/USP Dr. José Eduardo Butolo SUPRE MAIS

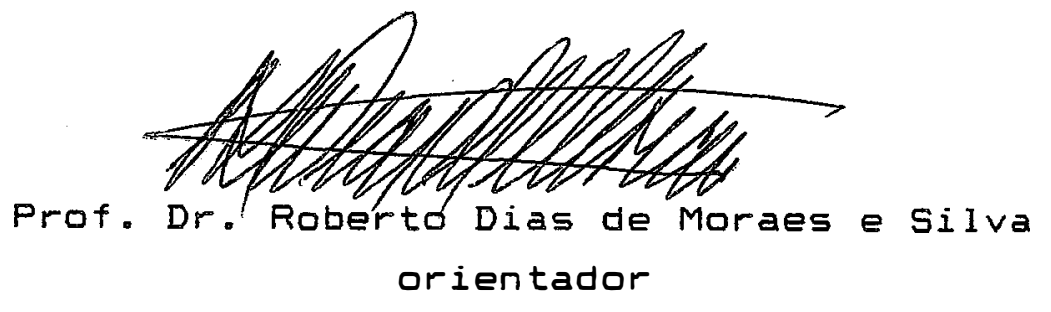




\begin{abstract}
Aos meus pais que me ensinaram que para tudo nesta vida há soluçăo, bastando para tal, acreditarmos na nossa capacidade de se realizar e de ser feliz.
\end{abstract}

Dedico

Ao meu marido e amigo
Moacyr, por estar ao meu
lado em todos os momentos.
ofereço


AGRADECIMENTOS

Ao professor Dr. Roberto Dias de Moraes e Silva, na qualidade de orientador, pela oportunidade de partilhar do seu conhecimento, podendo contar com o seu apoio, incentivo e amizade.

Ao Moacyr, meu marido, pelas tantas horas dedicadas a realizaçao deste trabaliho.

Aos colegas do curso que estiveram presentes nesta caminhada, sempre com mensagens de otimismo.

Ao funcionário do departamento de Zootecnia, Sr. Eliseu Poli, pela sua dedicaça e eficiente colaboraça, que tornaram possivel a realizaça deste experimento.

As amigas e funcionárias da biblioteca Eliana Maria Garcia Sabino e Katia Maria Pita de Andrade.

A SUPRE MAIS - ELM, pelo suplemento mineral e vitaminico e as analises experimentais que foram gentilmente cedidos.

A CAPES, pela bolsa de estudo concedida.

A FAPESP, pelo auxilio financeiro para realizaça do experimento.

E finalmente, a todos aqueles que direta ou indiretamente deram sua colaboraçă, tornando possivel a realizaça deste estudo. 
LISTA DE TABELAS..........................

RESUMO..............................viii

SUMMARY. .............................

1. INTRODUÇĂO............................

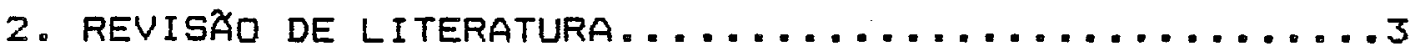

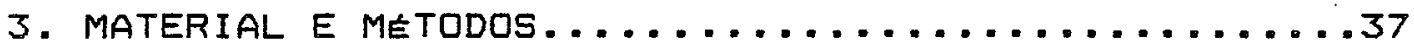

3.1. Instalaçoes e equipamentos experimentais.....37

3.2. Periodo experimental ....................

3.3. Aves experimentais.....................38

3.4. Manejo das aves.......................38

3.5. Composiçăo das raçôes experimentais........39

3.6. Obtençăo de dados.....................45

3.6.1. Temperatura ambiente..............45

3.6.2. Peso corporal ...................45

3.6.3. Consumo de raça.................46

3.6.4. Mortalidade e refugagem............46

3.6.5. Ganho de peso e conversao alimentar......46

3.7. Delineamento experimental...............47

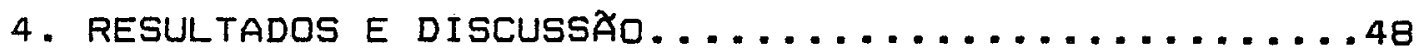

4.1. Análise de variancia..................48

4.1.1. Peso medio das aves..................48

4.1.2. Ganho de peso das aves..............52

4.1.3. Conversao alimentar das aves...........55

4.2. Forma de raço......................59

4.3. Granulometria do milho.................6s

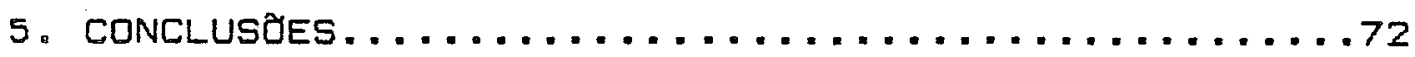

REFERENCIAS BIBLIOGRÄFICAS. ..............

APENDICE.............................. . . . . 
1. Resultados de análise do farelo de soja tostado utilizado nas raçøes experimentais...............40

2. Resultados de análise da farinha de carne e ossos utilizada nas raçoes experimentais...............40 3. Resultados de analise granulometrica do milho utilizado nas raçठিes experimentais..............41 4. Composiçăo centesimal da raçăo experimental . . . . . .42 5. Composiçao nutritiva calculada da raçăo experimental..............................43 6. Resultados das análises bromatológicas e granulometricas das raçoes experimentais ...............44 7. Análise de variancia do peso medio das aves aos 7 dias de idade...........................48 8. Análise de variância do peso medio das aves aos 14 dias de idade............................49 9. Análise de variância do peso medio das aves aos' 21 dias de idade.............................49 10. Análise de variância do peso medio das aves aos 28 dias de idade............................ 11. Análise de variância do peso medio das aves aos 35

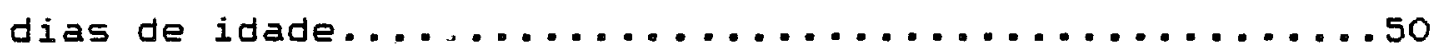
12. Análise de variância do peso medio das aves aos 42 dias de idade............................. 51 13. Análise de variancia do ganho de peso medio das aves durante a primeira semana de idade..........52 14. Análise de variância do ganho de peso médio das aves durante a segunda semana de idade...........53 15. Analise de variancia do ganho de peso médio das aves durante a terceira semana de idade.........53 16. Análise de variancia do ganho de peso médio das aves durante a quarta semana de idade..........54 17. Análise de variância do ganho de peso medio 
Tabela

Página

das aves durante a quinta semana de idade...........54

18. Análise de variancia do ganho de peso médio

das aves durante a sexta semana de idade............5s

19. Análise de variancia da conversao alimentar

das aves no periodo de 1 a 7 dias.................56

20. Analise de variancia da conversáo alimentar

das aves no periodo de 1 a 14 dias.................56

21. Análise de variância da conversaro alimentar

das aves no periodo de 1 a 21 dias...............57

22. Análise de variancia da conversáo alimentar

das aves no periodo de 1 a 28 dias...............57

23. Análise de variancia da conversao alimentar

das aves no periodo de 1 a 35 dias................58

24. Análise de variancia da conversao alimentar

das aves no periodo de 1 a 42 dias................58

25. Peso medio das aves segundo a fator

forma de raçáo $(7,14$ e 21 dias)................59

26. Peso médio das aves segundo o fator

forma de raçăo $(28,35$ e 42 dias)..............59

27. Ganho de peso medio das aves segundo o fator

forma de raçăo (primeira, segunda e terceira

semanas de idade).........................60

28. Ganho de peso médio das aves segundo o fator

forma de raçå (quarta, quinta e sexta

semanas de idade).........................6o

29. Conversao alimentar das aves segundo o fator

forma de ração $(1-7,1-14$ e $1-21$ dias......... .61

30. Conversao alimentar das aves segundo o fator

forma de raça $(1-28,1-35$ e 1-42 dias)............

31. Peso médio das aves segundo o fator

granulometria do milho $(7,14$ e 21 dias)...........6

32. Peso medio das aves segundo o fator

granulometria do milho $(28,35$ e 42 dias).........66 
33. Ganho de peso medio das aves segundo o fator

granulometria do milho (primeira; segunda

e terceira semanas de idade)...................67

34. Ganho de peso médio das aves segundo o fator

granulometria do milho (quarta, quinta e

sexta semanas de idade).....................67

35. Conversao alimentar das aves segundo o fator

granulometria do milho $(1-7,1-14$ e 1-21 dias)......68

36. Conversao alimentar das aves segundo o fator

granulometria do milho $(1-21,1-28$ e 1-42 dias).....68 
OS EFEITUS DA GRANULOMETRIA DO MILHO E FURMAS DE RAÇAO NO DESEMPENHO DE FRANGOS DE CORTE

\author{
Autora: MARLY KLINGER-CARDOSO \\ Orientador : Dr. ROBERTO DIAS DE MORAES E SILVA
}

Resumo

Realizou-se um experimento no Departamento de Zootecnia da ESALQ - USP, Piracicaba, Estado de Sao Paulo com o objetivo de estudar os efeitos da granulometria do milho e das formas de raça no desempenho de frangos de corte. Foram utilizados 900 pintos machos da I inhagem Hubbard criados até 42 dias de idade, os quais foram submetidos aos seguintes tratamentos: milho moido nas peneiras de $4,0,8,0$ e $12,0 \mathrm{~mm}$. de diametro de furo incorporado a raça, a qual foi fornecida sob as formas farelada e triturada. A raça utilizada no experimento foi única do ponto de vista nutricional, variando somente quanto ao tamanho da particula do milho e da forma utilizada. O delineamento experimental foi inteiramente casua1 izado empregando-se o fatorial $3 \times 2$ (granulometria do milho $x$ forma de raçao), tendo 5 repetiçaes por tratamento.

A interaçao forma de raçao e granulometria. do milho nå foi. significativa para todos parametros analisados (P>0,05). A diferenca entre os pesos medios a partir da segunda semana de idade foi significativa quanto a forma de racao $(P<0,05)$, sendo que as aves alimentadas com raça triturada estiveram mais pesadas que as alimentadas com a forma farelada. Aos 42 dias de idade, a granulometria do milho nao teve efeito significativo (P>0.05) sobre o peso das aves.

As conversoes alimentares nos periodos de 
1 a 7,1 a 14,1 a 21,1 a 28,1 a 35 e 1 a 42 dias de idade, com exceça do primeiro periodo, diferiram significativamente $(P<0,05)$, sendo que a forma triturada apresentou melhor resultado que a farelada.

A granulometria do milho da peneira de 8,0 $\mathrm{mm}$. determinou numericamente melhor conversao alimentar em todos os periodos analisados. A diferença entre o peso médio das aves foi significativa $(P<0,05)$ entre as granulometrias 4 e 8 vs. $12 \mathrm{~mm}$. até 35 dias de idade. Ao final do periodo experimental ( 42 dias) esta diferença desapareceu.

Concluindo, o uso de granulometria de média a grosseira do milho desde o primeiro dia de idade e viável, sem prejudicar o desempentio das aves, pois as diferenças significativas $(P<0,05)$ apresentada entre os pesos medios das aves nas três primeiras semanas entre as três granulometrias testadas desapareceram na fase final de criaçao, devido a um ganho de peso compensatorio à medida que as aves cresceram. A forma de raça que apresentou melhores indices de desempentio foi a triturada, independentemente do tamanho da particula de milho utilizada desde o primeiro dia de idade. 


\author{
EFFECTS OF CORN PARTICLE SIZE AND FEED FORM \\ ON BROILER PERFORMANCE \\ Author : MARLY KLINGER-CARDOSO \\ Adviser : Dr. ROBERTO DIAS DE MORAES E SILVA
}

SUMMARY

An experiment was carried out in the Department of Animal Science, ESALQ - USP, Piracicaba, state of Sao Paulo, in order to study the effects of corn particle size and feed form on broiler perfomance.

Nine hundred one day-old Hubbard male broiler chicks were brooded until 42 days of age subjected to the following treatments: corn was ground in a hammer mill with $4.0,8.0$ and $12.0 \mathrm{~mm}$ screen openings and used to formulate diets that were fed to broilers in mash and crumble forms. The diets used in the experiment were different only in the corn particle size and feed form. The experimental design was completely randomized using a $3 \times 2$ factorial (corn particle size $x$ feed form), with 5 replicates by each treatment.

There was no significant interactions between feed form and corn particle size for body weight, feed conversion and weight gain. From the second week of age on the difference in body weight was significant ( $P<0.05$ ) due to feed form, and the broilers fed crumble diet were heavier than the all mash form. At 42 days of age the effect of corn particle size on body weight was not statistically significant (P>0.05).

Feed conversion rates in the periods of 1 to 14,1 to 21,1 to 28,1 to 35 and 1 to 42 days of age were significantly different $(P<0.05$ ) by feeding crumbles rather than mash form. 
Broiler fed diet with corn particle size with $8.0 \mathrm{~mm}$ screen openings had the best feed conversion rate in all periods.

Body weight was also increased significantly $(P<0.05)$ by feeding corn particle size with 4.0 and 8.0 $\mathrm{mm}$ vs. $12.0 \mathrm{~mm}$ screen openings. At the end of the experimental period (42 days) this difference has disappeared.

It was concluded that the perfomance of broilers fed coarse and medium ground corn from the first day of age was not affected. The difference in body weight was statistically significant $(P<0.05)$ due to corn particle size during the first three weeks of age. This difference has disappeared from that age due to compensatory growth.

The crumble form promoted the better perfomance than mash, no matter corn particle size utilitized from the first day of age. 


\section{INTRODUÇÃ̄}

A alimentaçao é o item de maior custo na produçăo avicola, representando cerca de $70 \%$ dos custos totais. Baseando-se neste fato, e de grande importancia que se faça um rigoroso controle de qualidade dos ingredientes que irăo participar de uma raçăo, bem como a controle da mesma e a busca de tecnicas que melhorem a eficiência do processo de fabricaçao das raçâs.

Os alimentos utilizados nas raçoles avicolas săo moidos de maneira uniforme, para que não haja segregaçă das particulas por parte das aves, principalmente quando o alimento é fornecido na forma farelada. Mesmo assim, pode ocorrer um desequilibrio dos nutrientes, uma vez que certos ingredientes estao disponiveis em uma granulometria muito fina, podendo nao serem consumidos pelas aves.

Uma das maneiras de contornar este problema seria o fornecimento de raça nas formas granulada ou triturada. No entanto, mesmo utilizando estas formas, faz-se necessária a magem de determinados ingredientes.

o milho participa comumente de 60 a $70 \%$ do peso da raçăo, representando 40 a $50 \%$ dos custos totais. Portanto, qualquer aumento no rendimento da moagem do milho torna-se relevante sob o ponto de vista econômico, desde que o desempenho das aves nao seja prejudicado. A economia de energia resultante da substituicăo de uma granulometria fina para uma media é da ordem de $35 \%$, sem que o desempento das aves seja afetado. 


Baseando-se nestes fatos, o presente
trabalho teve por objetivo estudar o efeito da granulome-
tria do milho na alimentaço do frango de corte, ou seja,
verificar se com a utilizaça da granulometria mais gros-
seira há necessidade de se fornecer a racao de forma
granulada ou triturada.
As formas de raça comparadas foram a
triturada e a farelada, sendo que o milho foi moido no
moinho de martelo utilizando-se peneiras de diametros
$4,0,8,0$ a $12,0 \mathrm{~mm}$.


2. REVISÃo DE LITERATURA

Ds estudos relacionados com a tamanho das particulas dos alimentos e formas de raçao sobre o desempenho das aves vêm sendo realizados há mais de quarenta anos.

HEYWANG \& MORGAN (1944), compararam a

utilizaçao de raçoses nas formas farelada e granulada em machos e fêmeas em crescimento. O peso medio dos machos as 12 semanas de idade recebendo rasao granulada foi significativamente maior que dos machos que receberam raça na forma farelada. o peso medio das fêmeas tambem foi significativamente maior quando alimentadas com raçă granulada comparada a farelada as 12 e 22 semanas de idade. No primeiro dia de postura, as fêmeas que receberam raça na forma granulada apresentaram media de peso vivo significativamente maior que as fêmeas alimentadas com raçao farelada. No primeiro dia de postura, as fêmeas alimentadas com raçao granulada atingiram o mesmo peso que as aves alimentadas com raça farelada com 6 dias a menos de idade. Nao foram observados problemas de canibalismo.

BERG \& BEARSE (1947), trabalharam com o tamanho e formato das particulas de alimento no desenvolvimento das aves. Foram utilizadas raçes que variavam de uma granulometria grosseira a fina. As 8 semanas de idade, as aves pesaram em media 1.560 g quando alimentadas com raça grosseira em media $1.366 \mathrm{~g} \mathrm{com}$ raça fina. A raçăo fina ocasionou aderência do alimento no 
bico das aves prejudicando as mesmas, alem de problemas no papo.

ELEY \& BELL (1948), conduziram um experimento para avaliar o consumo de água das aves relacionado ao tamanho das particulas do alimento. Foram utilizadas três formas de raçao: raçăo grosseira, uma mistura de raça grosseira e fina e uma terceira raçăo moida finamente. Os autores concluiram que: o consumo alimentar, o consumo de água e excrȩ̣a de água aumentam com o aumento do tamanho da particula do alimento; nao houve diferença entre as dietas quanto ao ganho de peso $a$ o desperdicio de raçă foi maior na raça moida finamente, bem como na mistura de grosseira e fina.

outro experimento foi conduzido com relaรao ao consumo e eliminaçåo de agua por ELEY \& HOFFMANN (1949). Os graos neste experimento foram moidos no moinho de martelo, utilizando-se peneira com $1 / 2$ polegada de crivo. Este tamanho de peneira foi selecionado apos testes que mostraram que o grao inteiro nao passava neste crivo. Estes graos moidos de maneira grosseira foram misturados ao resto da raçăo e fornecidos de quatro formas: raçăo grosseira, raçao moida novamente com peneira de crivo de $1 / 4$ de polegada (raçao média), raça moida novamente com perieira de crivo de $2 / 32$ de polegada (raçao fina) e a rạ̧a media de forma granulada. Nas condiçôes do experimento, o tamanho da particula nao afetou a umidade das fezes, o consumo de água e alimento, nem o ganho de peso. Quanto ao desperdicio de raçăo, a raçăo encontrada em maior quantidade ns bebedouro foi a moida mais fina.

STEWART \& UPP (1951), compararam o desempentio de frangos alimentados com raçoes nas formas granulada, farelada e triturada até 12 semanas de idade. Os autores concluiram que a forma da dieta náo afetou a taxa de crescimento e a eficiencia alimentar. Houve 
tendência de maior ocorrência de canibalismo nas aves alimentadas com raça granulada e triturada e o rendimento de carcaça foi similar nas três formas de raçăo.

DAVIS et alii (1952), trabalharam com milho moido em moinho de martelo, onde utilizaram penei-. ras com crivos: 2/32", 5/32", 6/32", 8/32", 12/32" e 16/32". Os resultados indicaram que o tamanho da particula do milho teve efeito no desenvolvimento das aves. As granulometrias de 8/32", 12/32" e 16/32" prejudicaram o crescimento das aves. No inicio as aves preferiram as particulas menos grosseiras. Apos este curto periodo passaram a selecionar e preferir as particulas mais grosseiras em relaçao as outras da dieta.

BEARSE et alii(1952), compararam diferentes niveis de fibra no fornecimento da dieta nas formas farelada e granulada. Foram comparadas três raçôs sendo a primeira com $66 \%$ de milho, a segunda com $35 \%$ de milho $e$ $35 \%$ de cevada, e a terceira com $39 \%$ de milho e $35 \%$ de trigo. Aproximadamente com 10,5 semanas de idade, o peso médio das galinhas foi $0,072 \mathrm{~kg}$ maior na raça granulada de milho comparada com a farelada. A granulaçao da ração milho-cevada aumentou a peso medio em $0,127 \mathrm{~kg}$, bem como no milho-trigo onde o aumento no peso médio foi de 0,15 kg. A.granulaçåo, segundo os autores, aumentou a eficiência de crescimento e este aumento foi progressivamente maior a medida que o teor de fibra na raçă aumentou. As aves alimentadas com raçao granulada com alto teor de fibra, exceçao a de $18 \%$ de fibra, estavam mais pesadas do que as alimentadas com alto teor de milho na forma farelada.

LANSON \& SMYTH (1955), trabalharam com raça nas formas farelada, granulada e uma mistura das duas. Os resultados permitiram concluir que as aves alimentadas com raça granulada obtiveram média de peso corporal, conversao alimentar e desempenho melhores em 
relaçă as duas outras formas fornecidas. Ds autores atribuiram estes resultados ao fato de que as aves gastam menos tempo para se alimentar e dispendem menos energia com a uso de raçă granulada, sendo que este efeito positivo foi mais acentuado nas duas ultimas semanas de crescimento. 0 aumento na densidade do alimento permitiu aos frangos atenderem as suas exigências nutricionais de maneira mais eficiente.

A fim de estudar o efeito da granulaça na promoção do crescimento das aves, ALLRED et alii (1956), conduziram experimentos comparando três formas de raça: farelada, granulada e triturada. Foi obtido um aumento na taxa de crescimento das aves alimentadas com raçao nas formas granulada e triturada. Os autores sugeriram que este resultado se deve as alteraçoes quimicas que ocorreram nos ingredientes. Em outro experimento, onde os ingredientes foram granulados separadamente, os mesmos autores concluiram que a milho foi o mais afetado pela granulaçăo, a a submeterem o milho a diversos tratamentos (auto-clavagem, embebiçăo, granulaçăo) notaram ser a granulaçao o único processo que teve efeito no crescimento das aves.

JENSEN (1956), com a objetivo de estudar a razao do melhor desempenho no crescimento e eficiência alimentar das aves quando alimentadas com raça na forma granulada, conduziu um experimento comparando a utilizaఢ̧a de raçă nas formas farelada, granulada e triturada. Os resultados demonstraram que houve tambem modificaçoes do ponto de vista nutricional e quimico e naceapenas em relaça a forma fisica e a densidade, quando a raçă foi granulada. Para verificar esta hipótese, o autor granulou individualmente os ingredientes da raça (milno moido, farelo de soja e casca de aveial e depois de granulados, foram moidos e incorporados a raçao original. 0 único ingrediente que estimulou o crescimento quando 
granulado foi o milho. Em outros experimentos, o mesmo pesquisador concluiu que a granulaçao aumentou a disponibilidade de proteina para a animal e que certos inibidores do crescimento desconhecidos foram destruidos com - calor e a pressao envolvidos na granulaçao.

ALLRED et alii (1957a), conduziram alguns experimentos a fim de determinar o efeito da granulaça dos alimentos no desempenho de galinhas e perus e determinar o efeito da gordura animal e o nivel de proteina em relaçá a resposta obtida pela granulaçă. Os gränulas foram fornecidos triturados. O primeiro experimento comparou 0 uso de duas raçoes de alta energia, com gordura animal( $3 \%)$ e de baixa energia sem gordura animal nas formas farelada e triturada. A maior resposta a granulaçao foi observada com as dietas de baixa energia comparada com a de alta energia. Foi obtida maior resposta no crescimento $(P<=0.01)$ em todas as dietas na forma triturada. No segundo experimento, os autores estudaram o efeito da granulaçao antes $e$ depois da adiça de gordura. Os resultados indicaram uma resposta melhor no crescimento quando a dieta foi fornecida na forma triturada. O melhor resultado foi obtido quando a gordura foi adicionada antes da granulaça. Outro experimento relacionou o nivel de proteina da dieta $(20,22$ e $24 \%$ ) com a granulaçă, onde concluiram nåo haver interaçăontre 0 nivel de proteina e a granulaçao. As conclusoes finais foram de que a granulaçăo favoreceu o crescimento e a eficiencia alimentar em ambas as espécies. A resposta a granulaça foi positiva mesmo quando os granulos foram triturados. A adiça de gordura năo afetou o crescimento quando utilizada na raçăo granulada e o melhor desempenho das aves se deveu a inativaçao de inibidores do crescimento.

ALLRED et alii (1957b), conduziram outros experimentos onde os ingredientes foram granulados indi- 
vidualmente, a fim de estudar as mudanças quimicas e a inativaçao de fatores inibidores do crescimento. No primeiro experimento os autores concluiram que o milho foi - único ingrediente afetado pela granulaça, as aves alimentadas com $a$ milho granulado $e$ triturado foram mais pesadas que as aves que receberam milho moido, embora esta diferença nao tenha sido estatisticamente significativa. A eficiencia alimentar foi significativamente melhor $(P<=0,05)$ quando alimentadas com todos ingredientes granulados e triturados (milho, farelo de sojae aveia). A resposta no crescimento foi significativamente maior $(P<=0,05)$ quando as aves foram alimentadas com raçao triturada. No segundo experimento os autores compararam vários tratamentos do milho: vapor, autoclavagem, embebiça e granulaço. As aves que receberam o milho granulado triturado ou raça na forma granulada foram significativamente mais pesadas $(P<=0,01)$ que as aves que receberam raçao nå granulada. A granulaçăo dos outros ingredientes, nao afetou o desempenho das aves.

HINDS \& SCOTT (1958), trabal haram com dois tipos de dieta, sendo uma comercial e outra semi-purificada, a fim de estudar o efeito da granulaçao do milho. o milho utilizado foi moido, granulado e triturado para assim ser incorporado a dieta. Quando a dieta comercial foi utilizada os melhores resultados de ganho de peso e eficiência alimentar foram obtidos com o uso do milho triturado. Na dieta semi-purificada, a utilizaça de milho triturado nao aumentou o ganio de peso, comparado com o milho moido sem ser granulado e triturado. Os autores explicaram este fato da seguinte forma : a granulaça do milho destruiu algum fator inibidor do crescimento. Desse modo a dieta comercial nao atingiu um nivel suficiente deste fator para inibir o crescimento das aves e na dieta semi-purificada a granulaçao do milho nao fez diferença, uma vez que o nivel dos fatores inibi- 
dores do crescimento era minimo, nao afetando o crescimento. Quanto a idade das aves, as alimentadas desde o primeiro dia com raçá triturada tiveram melhor desempenho que as aves que mudaram de farelada para triturada aos 7 e 14 dias de idade.

BOLTON (1960), trabalhou com a determinaçăo da digestibilidade da proteina, do bleo e dos carboidratos das raç0es nas formas farelada e granulada. Os resultados das análises quimicas indicaram que a granulaçăo năo alterou a composiçăo quimica. A taxa de crescimento e a eficiência alimentar foram melhores com o uso de raçăo granulada, segundo o autor devido aos seguintes fatores: melhora na palatabilidade, aumento na densidade, quebra de componentes dos alimentos pelo tratamento com calor e destruicao de fatores inibidores do crescimento. Năo houve diferença entre as duas formas de raça quanto a digestibilidade.

PEPPER et alii (1960), conduziram uma série de experimentos para determinar a relaçao entre gordura, fatores năo identificados e granulaçao na alimentaçao de galinhas e perus. A adiçă de gordura a raçao farelada proporcionou um aumento no ganho de peso, ao passo que na raça granulada, fez com que diminuisse - ganho de peso progressivamente; estes resultados indicaram que as galinhas e os perus sao incapazes de consumir raça na forma farelada suficiente para atingir as suas exigências energeticas, por isso a inclusao de gordura determinou uma resposta positiva no ganho de peso. Por $f i m$, os autores sugeriram mais uma vantagem da raça granulada, ou seja o seu efeito economizador de gordura. A presença na raçăo farelada de alimentos fontes de fatores nao identificados como a farinha de peixe $e$ soro de leite desidratado, melhoraram a ganho de peso devido a sua capacidade de aumentar o consumo alimentar por parte da aves. 
REDDY et alij (1962), estudaram a relaçao entre a energia metabolizável e produtiva em raçoes nas formas farelada e granulada. Os resultados do experimento levaram os autores a concluirem que a energia metabolizável nao foi afetada pela forma da raçăo, mas a raçăo granulada teve $30 \%$ a mais de calorias de energia produtiva que a raçăo farelada, 口 que indicou uma diminuição no incremento calórico do alimento. Esta reduçăo no incremento calorico foi devido ao menor gasto de energia das aves ao se alimentarem.

MCINTOSH et alii (1962), conduziram tres experimentos para estudar os efeitos da moagem, da granulaça e do uso de pedrisco em uma dieta balanceada quanto a energia metabolizável sobre o desempenho das aves. 0 primeiro experimento objetivou estudar os efeitos da moagem, granulaça $e$ o uso de pedrisco nos valores de energia metabolizável do trigo e da cevada. Dessa manei$\mathrm{ra}$, os cereais foram fornecidos inteiros, moido fino, granulado e granulos moidos com e sem pedrisco. 0 método para determinar a energia metabolizável foi o da coleta total, devido a dificuldade em se misturar os graos ao sesquidxido de cromo. Os resultados de energia metabolizável mostraram haver uma interacăo significativa entre os graos, isto é, enquanto na cevada todas as formas apresentaram o mesmo nivel de energia metabolizável, no trigo, o grao inteiro apresentou maior conteúdo de energia metabolizável $(P<0,01)$ que as outras formas. 0 uso de pedrisco nå afetou o conteúdo de energia metabolizável dos graos. Quanto ao desempentio das aves, os cereais em granulos foram as que resultaram em maior ganho de peso e melhora na eficiência alimentar.

0 segundo experimento visou estudar melhor os efeitos do tamanho das particulas moidas e o uso de pedrisco sobre os valores de energia metabolizável. Os tratamentos foram, o trigo e a cevada fornecidos intei- 
ros, moido fino, grosseiro e medio com e sem pedrisco. Neste caso foi utilizado o sesquidxido de cromo com água. Neste experimento também houve uma interaça significativa entre grãos $(P<0,01)$, isto $e, 0$ trigo inteiro apresentou maior energia metabolizável que as outras formas, enquanto a cevada inteira apresentou menor energia metabolizável que as outras formas. A moagem da cevada contribuiu para aumentar a energia metabolizável. A moida fina apresentou valores maiores do que as outras formas. - uso de pedrisco aumentou significativamente $(P<0,01) 0$ valor de energia disponivel de trigo e da cevada, principalmente no grăo fornecido inteiro. 0 melhor desempenho das aves se deu quando foram utilizados graos de trigo inteiros e cevada moida. O terceiro experimento estudou - efeito da granulaça, moagem e o uso de pedrisco sobre - conteúdo de energia metabolizável dos cereais aveia, trigo, cevada e milho em três formas inteiro, moido médio e granulada. Foram utilizados dois tipos de dieta : balanceada e nåo balanceada (cereal como único ingrediente). o uso do pedrisco nao determinou diferença estatistica no valor da energia metabolizável em relacă a ausência do pedrisco. Com exceça da cevada, a granulaçăo dos cereais melhorou a eficiência alimentar e aumentou o ganho de peso. Comparando os resultados das aves alimentadas com o gráo inteiro e moido, nao se constatou diferença significativa. Ds autores concluiram que os resultados sugeriram que o balanco da dieta pode exercer uma variaçao na energia metabolizável e dependendo do tipo de grao e da forma, fisica do grăo estudado, embora nos resultados encontrados essa diferença não tenha sido significativa. 0 uso do pedrisco segundo os autores melhorou a energia disponivel, devido a moagem ocorrida na moela.

JENSEN et alii (1962), conduziram experimentos a fim de observar o modelo de alimentaço e 
determinar a taxa de passagem do alimento nas formas farelada e granulada. Quanto ao número de vezes que as aves se alimentaram a diferença foi pequena, variando bastante quanto ao tempo gasto para se alimentar. As aves que se alimentaram de raçăo farelada gastaram em média 7 minutos por refeiça, ao passo que as alimentadas com raça granulada gastaram menos de 1 minuto por refeiço. A porcentagem de tempo gasto para se alimentar foi de $18,8 \%$ em 12 horas e 2,2\% em 12 horas para raçao farelada e granulada, respectivamente. A determinaço da taxa de passagem foi feita com oxido de cromo, que foi encontrado em maior quantidade nas excretas entre a quarta sexta hora após a ingestao do alimento. Entre as formas farelada e granulada foi encontrada pouca diferença quanto a taxa de passagem. E possivel, segundo os autores, que as aves cresçam mais rapidamente com o uso de raça granulada, uma vez que gastam menos energia para preensao do alimento, restando mais energia para o crescimento.

HUSSAR \& ROBLEE (1962), conduziram estudos a fim de determinar o efeito da granulaça nas propriedades fisicas dos alimentos, a conteúdo de lisina dos grãos e o metabolismo energetico e proteico em aves de diferentes idades. A granulaçao aumentou a densidade em $24 \%$, sendo que os grânulos triturados apresentaram densidade menor que os granulos inteiros, mas maior que a raçăo farelada. o nivel de lisina năo foi afetado pela granulaçao. As aves alimentadas com raçao granulada ganharam 25\% mais peso e consumiram $15 \%$ mais alimento e tiveram uma eficiência alimentar $10 \%$ melhor que as aves alimentadas com raça farelada.

BAYLEY et alii (1968a), estudaram a influência de diferentes condiçoes de granulaçăo da dieta no desempenho das aves com diferentes niveis de proteina e lisina. O nivel de proteina que se mostrou adequado a 
forma farelada foi de $18 \%$ e para forma triturada foi de $23 \%$. A forma que determinou melhor ganto de peso foi a triturada. A adicao de lisina se mostrou positiva em dietas com baixo nivel de proteina. o tratamento de granulaça que teve melhor efeito foi o realizado na estaçao de Manitoba, onde o alimento foi submetido a temperatura de $70 \circ \mathrm{C}$ com vapor. Os melhores resultados apresentados com o uso da forma triturada foi devido ao menor gasto de energia pelas aves ao se alimentarem.

Em outro experimento BAYLEY et alii (1968b), estudaram os efeitos da granulaçao dos alimentos separados a em conjunto sobre a disponibilidade de fosforo, valor de energia metabolizável e a composiçăo da carcaça. Os resultados dos experimentos mostraram que a granulaça do milho e da soja aumentaram a disponibilidade de fósforo dos mesmos. a desempenho das aves e o teor de cinzas nos ossos sugeriram que a adiçao de $0,2 \%$ de fosfato inorganico fai adequado para as aves. Contudo a granulaçăo do milho e do farelo de soja separados năo apresentou nenhum efeito no desempenho das aves e no teor de cinzas dos ossos, sugerindo que o aumento da disponibilidade do fósforo foi causado pela liberaçăo do fósforo fiticoe da destruicao de compostos organicos que quelatavam o fósforo. As raçóes nas formas granulada e com farelo de soja granulado-triturado apresentaram niveis de energia metabolizável maiores que das raçôs na forma farelada e com milho granulado-triturado. A composiçăo da carcaça não foi afetada.

PFOST (1970), variou o diametro dos furos das peneiras usadas no moinho de martela de $1 / 32$ " a $2 "$, e concluiu que a medida que aumentava o tamanho do furo, a produçăo a capacidade aumentavam, porque a moinho realizou menor trabalho por unidade de peso do material a ser moida. Outro fator que aumenta o gasto de energia, segundo Friendrich citado por PFOST é o teor de umidade 
do material a ser moido, ou seja, quanto mais úmido maior o gasto de energia para a moagem, portanto com rendimento menor. Quanto ao tipo de grao, Silver citado por PFOST afirmou que os grãos com alto teor de amido foram mais facilmente moidos, com menor gasto de energia. AUCKLAND \& FULTON (1971), trabalharam com raçăo nas formas granulada, triturada e farelada. A taxa de crescimento foi maior com 0 uso de raçăo triturada comparada com a farelada, e este resultado foi encontrado com raçăo triturada com baixo nivel de energia (2.870 kcal EM/kg). No uso de raço farelada o melhor desempenho foi obtido com o uso de alto nivel de energia na dieta (3.000 kcal EM/kg).

AUCKLAND \& FULTON (1972), estudaram os efeitos da composiça nutritiva da dieta, das formas de raçåo (triturada e farelada) e a idade da matriz sobre o crescimento de frangos de corte. As aves alimentadas com raça triturada cresceram mais rapidamente que as aves alimentadas com raça farelada, e esta diferença a favor da raçao triturada foi maior nas raçaes com niveis nutricionais mais baixos. Esta interaçao entre composiça nutritiva da dieta e forma do alimento foi significativa $(P<=0,05)$. A mortalidade, embora sem diferença significativa, foi maior entre as aves alimentadas com a forma triturada. As aves provenientes de matrizes mais velhas foram significativamente mais pesadas ( $P<0,05$ ) ao nascerem e cresceram mais rapidamente do que as provenientes de matrizes jovens. No entanto, não houve interaçăo entre as formas de raçao e idade das matrizes. As aves alimentadas com rạăo na forma farelada ingeriram $7 \%$ mais alimento que as alimentadas com racao triturada. A granulaçao elou trituraçao do alimento fazem com que a eficiência de utilizaçăo da energia metabolizável aumente, porque neste caso as aves gastam menos tempo e energia para se alimentarem. o uso da racăo granulada ou 
triturada em todas as fases de alimentaça năo constitui problema uma vez que a diferença de peso que se nota no inicio, desaparece na oitava semana de idade, decorrente do ganho compensatório após um periodo de subnutriça.

RUNNELS et alii (1976), estudaram o efeito da textura do alimento sobre o desempenho de frangos de corte. As formas de raçao estudadas foram: granulada, granulada peneirada, triturada, metade granulada e metade triturada, e raçao farelada. Os resultados indicaram que as aves alimentadas com raçăo triturada estavam mais pesadas $(P<=0,01)$ e consumiram menos alimento por quilo de peso ganho $(P<=0,01)$. Esta observaçăo confirma a pratica comercial de alimentar os frangos até a quarta semana de idade com raçăo na forma triturada. Da quarta semana a oitava semana de idade, em todas as formas utilizadas comparadas com a farelada, as aves apresentaram peso significativamente maior $(P<=0,01)$ en relaça a forma farelada.

SIBBALD (1977), conduziu dois experimentos a fim de verificar os efeitos da granulaça no valor de energia metabolizável verdadeira em dietas para as aves. o autor nå encontrou diferença significativa (P>0,05) no valor de energia metabolizável verdadeira entre as raçôes farelada, granulada e triturada. A raçăo triturada com $0,25 \%$ de carbonato de potássic apresentou maior valor de energia metabolizável verdadeira que da mesma raça na forma granulada ( 3,96 vs. 3,76 kcal/g), contudo a diferença nå foi significativa. A conclusao final do autor é que a granulaçăcom vapor năo alterou o valor da energia metabolizável das dietas.

PROUDFOOT \& SEFTON (1978), conduziram dois experimentos para avaliar os efeitos da textura do alimento e da iluminaça sobre o desempenho de frangos de corte. A textura dos alimentos foi comparada nos seguintes tratamentos : dieta inicial (1-28 dias) triturada $e$ 
final (29-49 dias) granulada vs. uma dieta inicial e final fareladas com a presença de particulas finas, sob dois tipos de iluminaça, verde vs. branca continua e luz branca intermitente com tress niveis de intensidade ( 0 , 0,5 e 7 Lux). Os niveis de particulas finas foram : 0 , 5 , 15, 25, 35 e $45 \%$ Quanto a textura do alimento, os resultados indicaram que as aves alimentadas com raça triturada / granulada apresentaram, embora năo significativo, maior peso corporal e melhor conversao alimentar do que as aves alimentadas com raçao farelada: 0 aumento na proporça de finos na dieta, determinou um decréscimo no peso corporal e no retorno economico. Quanto ao programa de luz nao houve diferença no desempenho das aves sob as diferentes cores. A intensidade de luz baixa melhorou o crescimento das aves devido a reduçá no gasto de energia, em razao do menor deslocamento das aves. Năo houve interaça entre luz e textura do alimento.

DALE \& FULLER (1979), conduziram dois experimentos a fim de demonstrar a preferencia dos frangos de corte por dietas com alto nivel de gordura em condiçoes de inverno, quando as densidades energetica $e$ nutricional aumentam e quando a textura dos alimentos e igualada pela granulaçao. A preferência por dietas com alta gordura $(11,67 \%$ de óleo de aves) em relaça a baixa $(2,52 \%$ de dleo de aves) foi significativa ( $P<0,01)$, independente da temperatura ambiente. A textura do alimento nao influênciou significativamente a preferencia das aves por dietas com al to teor de gordura.

JONES (1979), afirmou que a avaliaçåo do custo da granulaça esta na dependência dos resultados obtidos quanto ao desempentio das aves alimentadas com raçăo granulada. A melhora no desempenho dependeu da idade das aves, da categoria das aves, do sexo, das condiçôs de granulaçăo e das condiçôes de manejo. 
ZELENKA \& SIROKY (1979), compararam a utilizaçao de dieta farelada e triturada por 3 semanas (raça inicial). o consumo foi maior e os ganhos de peso foram significativamente maiores com o uso de raça na forma triturada. Da terceira a setima semana de idade, as aves foram alimentadas com raçao granulada, sendo que a mudança de triturada para granulada foi mais gradual que de farelada para granulada. Durante este periodo as diferenças entre peso corporal diminuiram gradualmente e a setima semana de idade, os pesos corporais foram similares independente da forma fornecida inicialmente. Nå houve diferença entre as formas de raça quanto a conversao alimentar.

WENK \& ES (1980), conduziram experimento a fim de verificar os efeitos da granulaço na taxa de crescimento, na retença de energia, proteina e gordura e nas exigências de energia das aves. o experimento teve a duraçăo de 35 dias e foram utilizadas raçues nas formas farelada e granulada com os mesmos niveis de energia e proteina. A raça granulada garantiu $4,5 \%$ a mais de ganho de peso e $3,0 \%$ a mais no consumo de alimento. A retença de energia, proteina e gordura foi 5-6\% maior com 0 uso de raça granulada. As aves que se alimentaram de raçao na forma granulada foram menos ativas que as alimentadas com forma farelada. Os resultados indicaram uma economia de 5 a $7 \%$ na energia necessária para mantença $e$ de 2 a $3 \%$ no consumo de energia metabolizável total com o uso de raçăo granulada.

WILSON \& NESBETH (1930), trabalharam com codornas comparando a utilizaçăo de raçăo nas formas farelada e granulada. As aves foram alimentadas das seguintes maneiras: farelada durante as cinco semanas de vida, farelada nas duas primeiras semanas de vida seguida de granulada nas outras três semanas e granulada durante as cinco semanas de vida. As codornas alimentadas com 
ração granulada durante as cinco semanas tiveram ganio de peso superior ao das outras duas maneiras estudadas. A converså alimentar foi identica entre as raçôs farelada e granulada. A maneira de fornecer duas formas de raçă foi a que apresentou as piores resultados para conversão alimentar e ganho de peso, indicando um certo prejuizo quando a forma da raçao sofre mudança. A melhor maneira de se alimentar as codornas foi com o uso de raçăo granulada.

BRUE \& LATSHAW (1981), trabalharam com raça nas formas granulada e farelada para frangos de corte e constataram que os frangos alimentados com raçăo na forma farelada cresceram mais lentamente, e os frangos alimentados com raçăo granulada atingiram o mesmo peso 3 dias antes que os alimentados com a raça farelada. Os frangos consumiram mais energia metabolizável. por dia, depositaram mais gordura na carcaça quando alimentados com raçăo na forma granulada, demonstrando uma baixa capacidade das aves em regular a ingestao de energia.

SOUZA et alii(1982), conduziram um experimento comparando o uso de raçă nas formas farelada e granulada. A análise mostrou diferenças significativas entre os tratamentos para ganio de peso, consumo de raçăo e conversă alimentar em todas as fases (P<0,05). Desta forma os autores concluiram que aos 49 dias de idade as aves alimentadas com raça granulada apresentaram um ganho de peso 4,49\% maior, consumo de raçăo $2,71 \%$ maior e conversao alimentar $2,02 \%$ melhor que a raça farelada.

PROUDFOOT et alii (1982), estudaram o uso de raçă nas formas triturada e granulada sobre a incidência da sindrome da morte subita em frangos de corte machos. Os tratamentos utilizados foram rạăo triturada inicial e granulada final, raça triturada e granulada 
moida misturadas e raçă inicial e final fareladas. A mortalidade foi significativamente maior entre as aves que receberam rạ̧ăo triturada e granulada e ambas moidas comparadas a raça farelada $(P<0,01)$. 0 aumento de $1,24 \%$ na mortalidade foi devido principalmente ao aumento de 1,2 \% na incidência da sindrome da morte súbita. As aves alimentadas com raça inicial triturada e final granulada cresceram significativamente mais rapido que as aves dos outros dois tratamentos. As aves alimentadas com raça granulada-triturada moidas tiveram crescimento similar ao das aves que receberam raçao farelada, mas a mortalidade foi similar ao primeiro tratamento, permitindo concluir que a alta incidência da sindrome da morte subita foi devida a fatores nå identificados envolvidos no processo de granulaçåo e trituraçăo, e năo ao rápido crescimento. Do ponto de vista econômico o melhor tratamento recomendado pelos autores foi a de raça inicial triturada e final granulada, desde que o fator responsável pelo aumento da incidência da sindrome da morte súbita fosse el iminado.

PROUDFOOT \& HULAN (1982a), estudaram os efeitos do uso de raça nas formas farelada e triturada no tempo gasto pelas aves com alimentaça e sobre a incidência da sindrome da morte súbita. Os tratamentos consistiram na remoção do alimento por periodos de 0,8 , 10, 12,14 e 16 horas por dia, a partir dos 21 dias ate 49 dias de idade. A restriçăo alimentar teve um efeito significativo no peso corporal das aves aos 28 e 49 dias de idade, sendo que o peso corporal meihorou com o aumento no tempo de fornecimento de alimento. Quanto a forma da raçăo, as aves alimentadas com raçăo inicial triturada e final granulada apresentaram melhores resultados no desempento que as alimentadas com raça farelada. As aves alimentadas com raça triturada-granulada apresentaram um indice de mortalidade maior atribuido a 
sindrome da morte subita, principalmente nos machos. Apesar deste problema, os autores concluiram que o uso de raça triturada-granulada continuou sendo vantajoso do ponto de vista biológico e econámico, quando comparado com o uso exclusivo de raçăo farelada.

PROUDFOOT \& HULAN (1982b), trabalharam com perus a fim de verificar os efeitos da textura do alimento sobre o desempenho dos mesmos. O uso de raçao farelada nas fases inicial (0-21 dias), crescimento (22-70 dias) e final (71-98 dias) foram comparadas com outros cinco tratamentos que consistiam de raçăo inicial triturada e raçăo de crescimento e final granulada contendo $0,7,5$, 15, 30 e $60 \%$ de finos. Para a remoçao dos finos a raçào granulada foi peneirada em peneira de crivo $3,9 \mathrm{~mm}$. Os perus alimentados com raçăo inicial triturada apresentaram peso e na conversăo alimentar estatisticamente mel hores aos 21 dias de idade comparados com os alimentados com raçào farelada ( $P<0,05$ para machos e. $P<0,01$ para fêmeas). Aos 70 e 98 dias de idade somente o peso corporal das femeas diferiu significativamente ( $P<0,01)$, quando alimentadas com raça triturada comparada a farelada. A porcentagem de finos nao influênciou o desempento das aves. O retorno econâmico dependeu do custo com o processo de granulaça e do retorno extra por ave alimentada com a raçăo granulada.

SUTTON (1983), recomenda que na elaboraça dos grânulos, os graos de cereais devam ser moidos de tamanho medio ou fino, para aumentar a sua area de : exposiçă a gelatinizaçăo do amido e permitir a obtença de granulos de boa qualidade. Quanto a raça na forma triturada, salienta que ao se triturar o granulo, este deve ser cortado e nao esmagado, ou seja, a rólo a ser utilizado deve ser sulcado de modo que se torne cortante. Lembra tambem que os grânulos devem estar secos e frios para serem triturados. 
Segundo MCNAUGHTON (1984), muitos pesquisadores acreditam que a granulaçăo do alimento resulta em aumento da energia metabolizável, na reduça dos fatores toxicos (inibidor da tripsina, inibidor da quimotripsina, hemaglutinina, urease, salmonela, e outros), e na reduçăo do desperdicio de alimento, além dos grânulos requererem menor espaço para o armazenamento e facilidade de manuseio. As desvantagens apresentadas pela granulaçăo residem no fato de o calor e a umidade utilizados no processo ocasionarem a destruiçăo dos aminoacidos, vitaminas e antibioticos; ao alto custo do equipamento e a ocorrência de canibalismo entre as aves. Os resultados quanto ao aumento da energia metabolizável sao contraditorios. sibbald et alii(1960), citado por MCNAUGHTON (1984), concluiram que a densidade do nutriente influencia o ganho de peso das aves, explicando assim a melhora na eficiência alimentar com o uso de raça granulada. As pesquisas demostraram que a melhora no desempenho das aves supera o custo adicional do processo de granulaçăo, deixando assim este fator de ser uma desvantagem.

MCNAUGHTON \& REECE (1984), conduziram experimentos para determinar a relaçao entre energia da dieta granulada e o desempenho do frango do primeiro ao vigésimo oitavo dia de idade. As dietas foram fornecidas nas formas farelada e triturada e com três diferentes niveis de energia (3.100, 3.150 e $3.200 \mathrm{kcal} \mathrm{EM} / \mathrm{kg})$. O milho foi moido na peneira com $3,2 \mathrm{~mm}$ de crivo. As, dietas contendo 3.100 a $3.200 \mathrm{kcal}$ EM/kg resultaram em pesos estatisticamente equivalentes $(P>0,05)$. Os frangog: que se alimentaram de dieta triturada com 3.150 kcal EM/kg ganharam mais peso $(P<0,05)$ que os alimentados com raça farelada com o mesmo nivel de energia. A granulaço da ração com $3.100 \mathrm{kcal}$ EM/kg resultou em uma equivalencia estatistica ( $P<0,05)$ quanto a eficiência alimentar quando comparada com as granuladas com 3.150 e 3.200 kcal 
EM/kg. A granulaça aumentou a eficiência alimentar em $0,088 \mathrm{com} 3.100 \mathrm{kcal} \mathrm{EM} / \mathrm{kg}, 0,078 \mathrm{com} 3.150 \mathrm{kcal} \mathrm{EM} / \mathrm{kg}$ e $0,042 \mathrm{com} 3.200 \mathrm{kcal} \mathrm{EM} / \mathrm{kg}$ quando comparada com a mesmas dietas na forma farelada. Os resultados indicaram que a trituraçăo dos grânulos aumentou a eficiencia alimentar. As desvantagens da granulaçă vêm sendo reestudadas com - aparecimento de novas vantagens, como o aumento do nivel de energia, uma vez que raçâes de alta energia săo mais caras, logo uma avaliaça econômica deve ser feita, a fim de verificar a lucratividade da granulaçao versus o uso de dietas de alta energia.

REECE et alii (1984), conduziram um experimento com frangos de corte, onde avaliaram dois niveis de energia ( 3.032 e $3.109 \mathrm{kcal} \mathrm{EM} / \mathrm{kg})$, quatro niveis de proteina (17, 18,19 e $20 \%)$ em raçoes de crescimento e final nas formas farelada e triturada, a temperatura de 26,7 oC do vigésimo ao quadragesimo quinto dia de idade. Nos primeiros 21 dias de idade as aves receberam raça na forma farelada. 0 melhor resultado foi obtido com a dieta de alta energia, alta proteina e na forma triturada. A raça na forma triturada melhorou a conversåo alimentar em todas as dietas, exceto nas dietas de baixa proteina (17 e 18\%). O peso corporal aos 45 dias de idade das aves alimentadas com raçao triturada com 3.109 kcal $E M / k g$ a alta proteina foi significativamente maior $(P<=0,05)$ que das aves alimentadas com raçáo farelada. De um modo geral, a trituraçă das dietas de crescimento e final, aumentou o peso corporal das aves em $2,2 \%$ e melhorou a conversáo alimentar em 1,5\%. Granulando e triturando a raçăo com 3.109 kcal EM/kg obteve-se uma melhora na conversao alimentar de 1,7\%. Com a raçăo de $3.032 \mathrm{kcal}$ EM/kg, a conversalo alimentar melhorou $1,3 \%$. 0 mesmo ocorreu nos niveis de proteina, sendo que na baixa proteina a melhora na conversao alimentar foi de $1,3 \%$ e 
na alta proteina a melhora na conversão alimentar foi de $1,8 \%$.

PROUDFOOT et alii (1984), conduziram três experimentos a fim de determinar se a granulaçao afetava os micronutrientes, a gordura e os componentes proteicos da dieta e se este fato determinava o aumento da incidência da sindrome da morte súbita. No primeiro experimento, somente os micronutrientes foram granulados, triturados e incorporados a raça. Neste caso a incidencia da sindrome da morte súbita e a peso corporal nao foram significativamente afetados pela granulaça dos micronutrientes $(P>0,05)$. A conversao alimentar e o retorno econômico melhoraram numericamente com o uso de micronutrientes granulados e triturados, esta diferença foi significativa $(P<0,10)$. No segundo experimento a gordura estabilizada $a$ farelo de soja foram granulados separadamente. A prática de granulaçăo da gordura determinou uma melhora significativa no peso corporal aos 42 dias de idade $(P<0,05)$, quando comparada com os outros tratamentos (farelo de soja granulado e a dieta sem nenhum ingrediente granulado). No terceiro experimento o farelo de soja, a farelo de canola e a farinha de peixe sofreram granulaçao. Neste caso a mortalidade se reduziu devido a uma reduça de 3,61 para $0,90 \%$ da ocorrência da sindrome da morte súbita. a peso corporal foi menor quando comparado com o controle (sem granulaça), mas a conversăo alimentar nao foi afetada significativamente $(P>0,05)$. 0 retôrno econômico foi maior na raça controle, apesar da alta incidência da sindrome da morte súbita. Segundo os autores, os maiores efeitos da granulaçăo e trituraça recaem sobre as fontes proteicas, onde houve uma diminuiça na incidência da sindrome $e$ no peso corporal. A reduçăo na taxa de crescimento foi devida a destruiça incompleta do inibidor da tripsina no processamento do farelo de soja. E possivel que o maior agente causador da 
sindrome da morte súbita sejam os fatores toxicos produzidos quando os alimentos proteicos sao submetidos a granulaçăo e trituraçăo.

REECE \& LOTT (1985), estudaram a utilizaçă do moinho de cilindros na maggem do milho, sorgo e trigo, com o objetivo de reduzir o gasto de energia no preparo das raçôes. Os autores compararam os moinhos de cilindro e martelo e concluiram que as particulas dos graos moidos no moinho de cilindro sao consideravelmente maiores que no moinho de martelo, e a medida que se deseja uma particula de menor tamantio, maior será o gasto de energia.

No moinho de martelo a mudança do diametro do furo da peneira de $3 / 8$ para $3 / 16$ de polegada ou de $1 / 4$ para $1 / 8$ de polegada dobrou o gasto de energia. A conclusão final dos autores é que o moinho de cilindros moe de maneira adequada o milho, o sorgo e o trigo para o uso em raçao granulada. Outra observaça refere-se à forma com que a raçăo é fornecida as aves. Na forma farelada o método de moagem não tem importância alguma, no entanto., as aves estiveram mais pesadas com o uso da raçao na forma farelada com milho moido no moinho de cilindro, comparadas às aves que receberam raça com milho moido no moinho de martelo e peneira com diametro dos furos de $3 / 16$ de polegada.

REECE et alii (1985), conduziram um outro experimento onde compararam a utilizaçao de moinho de martelo ao de cilindros na moagem do milho, a fim de verificar a eficiência dos mesmos. Além disto, verificaram também os efeitos da granulaça da raçao no desempenho dos frangos de corte, e a existência de interacoes entre nivel energetico da dieta, granulaça e tipo de moinho. Utilizaram raça farelada e triturada, esta última com o objetivo de reduzir a variabilidade na qualidade do grânulo decorrente do manuseio e degradaça 
do mesmo. Durante os primeiros 21 dias de idade as aves foram alimentadas com duas formas de raça: farelada $e$ triturada. Para o periodo de 22 a 47 dias foram usados oito tratamentos envolvendo duas formas de raçao (farelada e triturada), dois tipos de moinhos para a milho (martelo e cilindros) e dois niveis de energia ( 3.032 e $3.109 \mathrm{kcal}$ EM/kg). O crivo da peneira do moinho de martelo era de $4,8 \mathrm{~mm}$. Os resultados aos 21 dias mostraram que as aves alimentadas com raça farelada com milho moido no moinho de martelo apresentaram menor peso e a pior conversao alimentar. a uso do moinho de cilindro para moer o milho na raça farelada aumentou a peso corporal e melhorou a conversa alimentar quando comparada com a raçăo farelada $e$ milho moido no moinho de martelo. Triturando-se as dietas com milho dos dois tipos de moinho obteve-se um aumento no peso corporal, sem efeito algum sobre a conversar alimentar. Esses resultados sugerem que se a raçao farelada for oferecida durante o periodo inicial ( 0 - 21 dias), o uso do moinho de cilindras ao invés do uso do moinho de martelo, melhoraria significativamente os pesos e a conversao alimentar ate 21 dias.

Os resultados até 47 dias demonstraram que a raçao triturada quando comparada a farelada com milho moido no moinho de martelo, melhorou significativamente - peso tanto dos machos como das fêmeas e melhorou a conversao alimentar. Houve uma interaça do tipo de moinho com os niveis de energia, isto e, a trituraçăo da raçao com milho moido no moinho de martelo aumentou o peso das aves em $4,4 \%$ a $3.032 \mathrm{kcal}$ EM/kg e $6,6 \%$ a 3.109 kcal EM/kg. Tanto a raça farelada como a triturada preparada com milho do moinho de cilindros, produziu aves mais pesadas que a raçăo farelada com milho de moinho de martelo. Os efeitos da trituraço sobre as 
dietas com milho do moinho de cilindros, sobre o desempenho das aves fai menor que do moinho de martelo.

0 moinho de cilindros consumiu $14,5 \%$ menos energia para moer o grá de milho. A particula de milho proveniente da moagem no moinho de martelo é mais fina (diametro $=814$ microns) que a particula do moinho de cilindro (diâmetro $=1,343$ microns). Segundo os autores, nao se sabe ao certo como a diferença no tamanto da particula afeta a taxa de crescimento das aves e a conversao alimentar. O uso do moinho de cilindros, que pudesse diminuir a energia necessaria para a moagem do milho em $14,5 \%$, pode melhorar significativamente o desempenho dos frangos de corte durante os primeiros 21 dias, quando a raçăo inicial é fornecida na forma farelada. Aparentemente o desempenho dos frangos de corte aos 47 dias, alimentados com raçăo triturada, năo deve ser afetado de maneira significativa se um moinho de cilindros for utilizado no lugar do moinho de martelo na moagem do grào de milho.

Segundo LOWE (1985), vários sáo os fatores a serem considerados na granulaçao e trituraçao dos alimentos e das raçäes. Alguns ingredientes como os medicamentos perdem sua potência quando submetidos ás altas temperaturas, devendo ser analisados após a granulaçao para verificar se houve a perda de sua atividade. Em relaçă as particulas finas, quanto maior a sua porcentagem maior será a perda de potência dos medicamentos, uma vez que necessitam de uma dupla granulaça. o uso de aglutinantes tambem pode constituir ur problema segundo o autor uma vez que pode tornar o microingrediente indisponivel para a ave. Outro fator a ser considerado na obtençao de uma raçăo de boa qualidade refere-se ao tamanho das particulas dos alimentos e sua densidade para que a mistura seja a mais homogenea possivel. 
CHOI et alii (1986), estudaram os efeitos das raçaes nas formas granulada e triturada sobre o desempento e desenvolvimento do sistema digestivo de frangos de corte. As aves alimentadas com raçao na forma triturada no periodo inicial (0-4 semanas) tiveram ganho de peso significativamente maior $(P<0,01)$ e consumiram significativamente mais alimento $(P<0,01)$ que com o uso de raçao na forma farelada. A granulaçă da raçăo final (4-8 semanas) melhorou o ganho de peso e a conversao alimentar significativamente $(P<0,01)$. Nă foi encontrada interaça significativa entre as formas de raçăo inicial e final, embora numericamente as aves alimentadas com raçă inicial farelada e final granulada apresentaram maior ganho de peso. Quanto ao sistema digestivo, a alimentaçăo na forma triturada durante o periodo inicial resultou em uma diminuiça significativa $(P<0,05)$ do peso da moela as 4 semanas de idade. A alimentaçăo no periodo final na forma granulada, tambem reduziu significativamente $(P<0,01)$ o peso do trato digestivo e da moela as 8 semanas de idade comparada com a raça na forma farelada. A interaça entre as formas de raça inicial e final e o tamanho do sistema digestivo nå foi significativa. Como conclusao final, os autores sugerem que a alimentaçăo com raçao farelada no inicio e granulada no final foi tăo eficiente quanto a utilizaçăo de raço nas formas triturada ou granulada durante os dois periodos.

MILOSEVIC et alii (1986) trabalharam com as seguintes linhagens de frangos de corte: Hybro, Ross, Hubbard, Prelux-Bro e Vedette, alimentadas com raçaes nas formas granulada e farelada. Os resultados encontrados de peso aos 49 dias de idade foram respectivamente: $1,832,1,818,1,922,1,556$ e $1,635 \mathrm{~kg}$ com dieta granulada e 1,669, 1,628, 1,677, 1,457 e 1,573 kg com dieta farelada. As conversoes alimentares encontradas foram: 
$2,419,2,439,2,318,2,189$ e 2,304 e 2,565, 2,469, $2,633,2,353$ e $2,353 \mathrm{~kg}$ de alimento por $\mathrm{kg}$ de peso ganho nas formas granulada e farelada, respectivamente.

MOKHAMED (1986), conduziu experimento a fim de verificar os efeitos do nivel de energia e da granulaçăo no desempenho de frangos de corte. Os resultados encontrados foram: peso aos 56 dias de idade, raçăo granulada $1,648 \mathrm{~kg}$ (baixa energia) e $1,719 \mathrm{~kg}$ (alta energia), raça farelada 1,588 kg (baixa energia) e $1,618 \mathrm{~kg}$ (alta energia); consumo de raçăo granulada $2,390 \mathrm{~kg}$ (baixa energia) e $2,341 \mathrm{~kg}$ (alta energia), raça farelada $2,778 \mathrm{~kg}$ (baixa energia) e 2,651 kg (alta energia).

REECE et alii (1986a), conduziram um experimento com os objetivos de comparar o uso de raça nas formas granulada e triturada sobre o desempenho de frangos de corte, relacionado a temperatura na qual as aves foram criadas, e avaliar os efeitos da granulometria do milho sobre o desempenho das aves, a durabilidade do grânulo e a energia necessária para moagem do milho. As aves foram submetidas as temperaturas de 29,4 -C na primeira semana, 26,7 oC na segunda semana e 23,9 - C na terceira semana. A partir dos 21 dias de idade, metade das aves foram submetidas a 27,0 oC de temperatu$\mathrm{ra}$, onde permaneceram até 45 dias de idade, e a outra metade esteve a temperatura de 21,0 oC até 42 dias de idade. o milho foi moido em um moinho de martelo com crivos de peneiras de $4,76 \mathrm{~mm}$ e $6,35 \mathrm{~mm}$. As raçôes iniciais preparadas com os dois tamanhos de amilho moido foram fornecidas na forma triturada ( grânulos triturados no moinho de cilindros). As raçoes de crescimento tambem preparadas com os dois tamanhos de milho, foram fornecidas nas formas granulada e triturada. Os resultados encontrados aos 21 dias de idade demonstraram nao haver efeito significativo do tamanho da particula do 
milho tanto sobre o peso corporal como na conversao alimentar, o que indica que a utilizaçăo de raçao triturada aliada ao tamanho da particula do milho nao influenciou o desempenho do frango de corte, e proporcionou uma redução no gasto de energia, uma vez que o rendimento da moagem a $6,35 \mathrm{~mm}$ é $27 \%$ maior que a $4,76 \mathrm{~mm}$. A raça de erescimento na forma granulada a 21,0 oc aumentou a peso final em 6,5\% comparada com a raça triturada, assim como a conversao alimentar que foi $0,7 \%$ melhor para as aves alimentadas com raçăo granulada comparada a triturada. Quanto a granulometria do milho, nao houve efeito desta sobre a peso corporal e conversa alimentar.

Há uma tendência em melhorar o desempenho quando se utiliza granulometria mais fina do milho na elaboraçao dos grânulos e tendencia contrária quando se utiliza raçăo triturada. Mas o aumento no gasto de energia, quando se utiliza o crivo de $4,76 \mathrm{~mm}$ nao justifica o aumento no desempenho do frango. A temperatura de 27,0 o $C$, uso de raçăo granulada aumentou 0 peso corporal em $1,8 \%$ comparada com a raçăo triturada. A granulometria do milho nao teve efeito sobre as aves a esta temperatura. Năo houve indicaçனes de que a granulometria do milho afetava a qualidade do grânulo.

Em outro experimento REECE et alii (1986b), estudaram os efeitos do moinho de martelo na granulometria do milho e os efeitos desta variaça na granulometria sobre o desempenho dos frangos e durabilijade do granulo. As aves foram criadas ate 21 dias submetidas a 29,4 oC na primeira semana, 26,7 oC na segunda semana e $23,9 \circ \mathrm{C}$ na terceira semana, de 21 a 42 dias de idade a temperatura variou de 21,0 a 24,0 oC. O milho foi moido en moinho de martelo com três diferentes crivas de peneira: $3,18 \mathrm{~mm}, 6,35 \mathrm{~mm}$ e $9,53 \mathrm{~mm}$. A raça inicial foi na forma triturada e a raça final na forma 
granulada. Nå houve diferença no desempenho das aves entre a granulometria fina $(3,18 \mathrm{~mm})$ e grosseira $(9,53$ $\mathrm{mm})$, e estas determinaram melhor ganho de peso e conversăo alimentar, quando comparadas com a de $6,35 \mathrm{~mm}$, tanto na fase final, como em todo o periodo experimental. O milho moido de granulometria grosseira (9,35 $\mathrm{mm}$ ) conferiu maior durabilidade ao granulo.

Ds resultados indicaram, segundo os autores que ao contrário do que se acredita a moagem do milho com tamanho proximo aos outros ingredientes da raçă, não determina melhora no desempento das aves e na durabilidade do grânulo. Além deste fato, o uso de crivo maior da peneira na moagem do milho resulta em uma reduçăo substancial no consumo de energia.

REECE et alii (1986c), conduziram um experimento para verificar os fatores que afetam a prática da restriça alimentar ou do controle alimentar em frangos de corte. A forma de raça foi um dos fatores estudados. Foram comparadas as formas triturada e granulada. Q alimento foi fornecido 3,5 horas e retirado 4,5 horas resultando em três ciclos por dia, 2 horas e retirado 2 horas, resultando em seis ciclos por dia comparados com o fornecimento ad libitum. 0 uso de raçăo triturada apresentou melhores resultados comparada a forma granulada em condiçøes de alta temperatura.

BERTECHINNI (1987), conduziu experimento com o objetivo de estudar os efeitos da granulaçao das raçbes com diferentes niveis de energia sobre a desempenho e a qualidade da carcasa de frangos de corte. Aumentos lineares ( $P<0,05$ ) no ganho de peso e gordura corporal foram obtidos com o aumento dos niveis de energia da raçăo, havendo reduçăo linear $(P<0,05)$ no consumo de raçăo teor de água corporal e melhoria linear ( $P<0,01$ ) na conversao alimentar no periodo de 1 a 56 dias de idade das aves. O maior nivel de energia $13.200 \mathrm{kcal}$ 
EM/kg) resultou em maior rendimento da carcaça $(P<0,05)$, quando comparado com os autros niveis de energia (3.000 e $2800 \mathrm{kcal}$ EM/kg), que nao diferiram entre si (P>0,05). A granulaçăo das raçôes possibilitou maiores ganhos de peso e consumo de raçao sem influir ( $P>0,05$ ) na conversăo alimentar, no rendimento de carcaça e nos teores de gordura, água e proteina corporal. Os efeitos da granulaçăo sobre o gantio de peso e consumo de raçăo foram diminuindo a medida que se aumentaram os niveis de energia das raçbes. Como conclusăo final, o autor afirma que o uso de raçoes na forma granulada favorece o desempento das aves, sendo que os maiores beneficios saa encontrados em raçoes de menor densidade calórica.

HULAN \& PROUDFOOT (1987), conduziram experimento com frangos pesados; onde avaliaram os efeitos do fosfato dibásico de calcio e a textura do alimento sobre a incidência de problemas de pernas e sobre o desempenho das aves. A raça inicial foi fornecida na forma triturada, e as de crescimento e final nas formas farelada e granulada. A interaça entre o acesso a fonte mineral e a textura da raça nă foi significativa.

0 acesso livre ao fosfato de calcio resultou em um aumento do consumo de cálcio e fósforo, reduziu o peso corporal aos 21 dias de idade, aumentou a taxa de mortalidade e a ocorrencia de discondroplasia tibial e problemas de pernas.

As aves alimentadas com raça de crescimento e final granuladas estiveram mais pesadas aos 51 dias, apresentaram pior conversăo alimentar, maior incidência de discondroplasia tibial e maior incidência de mortalidade devido a sindrome da morte súbita quando comparadas com as aves alimentadas com raça farelada. Concluiram assim que o uso de raça farelada, a qual determinou melhores resultados é recomendável para frangos pesados. 
DEATON et alii (1987), trabalharam com poedeiras submetidas a altas temperaturas $(24,35,24$ oc) a fim de verificar o uso de racáo nas formas granuladas e farelada em condiços de verăo. Os resultados indicaram que nestas condiçoes, a granulaçăo năo aumentou o ganho de peso entre a décima segunda a vigésima semana de idade quando comparada a forma farelada. Quando submetidas a uma temperatura moderada (210C), a granulaçao nå teve efeito sobre o ganho de peso, mas afetou significativamente $(P<0,05)$ o consumo alimentar quando comparada ao consumo das poedeiras submetidas a altas temperaturas. Os autores concluiram que a granulaça nå constitui uma saida para aumentar o consumo de alimento na epoca mais quente do ano.

BUTOLO et alis (1987), com o intuito de verificar os efeitos causados pela granulometria inadequada do milho na alimentaça de frangos de corte, no periodo de 1 a 28 dias, conduziram experimento onde utilizaram o milho moido em peneiras de $2,0,3,0,4,0$, 6,0 e $8,0 \mathrm{~mm}$. Os resultados obtidos mostraram nao haver diferença significativa no ganho de peso, consumo de raçăo conversào alimentar das aves nas diferentes granulometrias, apenas uma certa tendencia das aves alimentadas com milho moido na peneira de $2,0 \mathrm{~mm}$ apresentarem melhor ganho de peso e conversao alimentar no periodo de 1 à 14 dias de idade.

SILVA et alii (1988), conduziram um estudo para verificar se o uso de raça granulada influenciava a incidencia de ascite en frangos de corte submetidos a baixas altitudes (730 $\mathrm{m}$ acima do nivel do mar). Os autores observaram que as aves alimentadas com raça na forma granulada apresentaram melhor ganho de peso $e$ melhor conversao alimentar. No entanto a taxa de mortalidade foi mais alta. A incidencia de ascite foi muito baixa para permitir conclusoes definitivas, mas segundo 
os autores muitos nutricionistas e veterinários afirmam que qualquer fator que acelere o crescimento ou melhore a conversao alimentar, contribuirá também para um aumento na incidência de ascite.

DEATON et alii (1988), conduziram experimento com o objetivo de estudar o efeito da debicagem aos 50 dias de idade de frangos de corte pesados, no consumo de alimento e no peso corporal, quando o alimento foi fornecido nas formas farelada e granulada. Nao houve diferença significativa entre os tratamentos (debicagem $0,5 \mathrm{~cm}$ e $0,75 \mathrm{~cm}$ ) em relaçăo a forma da dieta (farelada e granulada).

PLAUNIK \& HURWITZ (1989), conduziram experimento de restriçăo alimentar, onde utilizaram raçăo granulada a fim de aumentar a densidade nutricional da dieta. A restriça alimentar foi aplicada do sexto ao decimo terceiro dia de idade. Durante estes dias as aves receberam uma dieta com o nivel de energia necessário apenas para manter o seu peso corporal. Us resultados mostraram que a ganho de peso aumentou com o uso de raçăo granulada. A eficiência alimentar nào foi afetada. No entanto nåo houve interaçăo entre a forma da raçăo e restriço alimentar, isto é em nenhuma variável medida, a forma de fornecimento da raça modificou a resposta obtida com a restricăo alimentar. A gordura abdominal diminuiu com a restriça alimentar, independente da forma de raça utilizada.

Vários trabal hos foram apresentados no $X X V$ Congress of the Israel Branch of the worlds Poultry Science Association, (Poultry International - Maio de 1989), descrevendo aspectos da utilizaçăo de raçdes nas formas granulada e triturada para frangos de corte. Em trabalho realizado pela integraça Milonoth, onde foi comparada a utilizaçăo de raçăo granulada e triturada dos 35 aos 49 dias de idade, a raça granulada foi a que 
determinou maior peso e melhor conversao alimentar em relaçăo a triturada, mas aumentou o consumo de água e a umidade da "cama". Outro trabalino apresentado, foi conduzido com o objetivo de determinar a idade ideal para a mudança da forma de raça triturada para granulada. Os tratamentos foram forma triturada durante os 49 dias de idade $e$ raçao na forma granulada seguida de triturada com mudança aos $21,28,35$ e 42 dias de idade. Ds pesquisadores concluiram que os granulos podem ser fornecidos até a ave atingir $600 \mathrm{~g}$ de peso (até 21 dias). Dutro trabalho apresentado, comparou a moinho de martelo ao de cilindro na moagem de sorgo, onde observaram que a granulaçăo da dieta contendo sorgo moido no moinho de martelo resultou em melhor taxa de crescimento das aves, já com o sorgo moido no moinho de cilindro a granulaçào nao teve efeito nenhum sobre o desempenho das aves. Concluindo, com dietas fareladas a moagem do sorgo no moinho de cilindro teve um efeito marcante sobre o desempenho das aves, com uma tendência contrária em relação as dietas trituradas.

DEATON et alii (1989), conduziram experimento para avaliar os efeitos da granulometria do milho sobre o desempento de poedeiras. 0 milho foi moido em moinho de cilindro e de martelo com diametro das particulas variando de 1,343 a 1,501 microns e de 814 a 873 microns respectivamente. O método de moagem nao influenciou significativamente o desempenho das poedeiras tanto no peso corporal, como no peso dos ovos, eficiência alimentar, eficiência de produça, resistência da casca do ovo e mortalidade.

Segundo PORTELA (1989), o tamanho da particula afeta a ingestao de alimento por parte das aves. Estas apresentaram dificuldades em se alimentar de particulas muito pequenas em relaça ao tamanho do seu bico. Freqüentemente aparecem relatos que as aves cres- 
cem mais rapidamente quando alimentadas com raçăo na forma granulada em comparaça com a forma farelada. Isto se deve ao fato das aves gastarem menos tempo para se alimentar e menos energia. Em um trabalho feito pelo autor, os resultados mostraram que as poedeiras tem o seu consumo de raçao afetado somente com a mudança no tamanho da particula do alimento e necessitam de quatro dias para ajustar o consumo de alimento após a mudança no tamanho da particula.

PROUDFOOT \& HULAN (1989), estudaram os efeitos da textura do alimento sobre o desempenho de frangos pesados criados ate 63 dias de idade. Foram utilizadas as formas de raça farelada (milho e trigo moidos fino, medio e grosseirol, triturada e granulada (milho e trigo moidos fino e medio). A raçăo inicial (o21 dias), foi fornecida nas formas farelada e triturada, as raçoes de crescimento (22-49 dias) e final (50-63 dias), nas formas farelada e granulada. o experimento foi realizado no veráo no outono. As aves alimentadas com raçao farelada com os ingredientes moidos de maneira fina e grosseira, apresentaram uma taxa de mortalidade inferior a das aves alimentadas com as formas triturada-granulada. Este fato ocorreu devido a alta incidencia da sindrome da morte subita. A moagem fina e grosseira na raçăo farelada resultou em pior conversão alimentar aos 21 dias $e$ aos 49 dias $(P<0,001)$. Os frangos pesados alimentados com raçăo triturada-granulada exibiram pesos corporais significativamente $(P<0, O 5)$ maiores do que os alimentados com raçà farelada, independente do tamanho das particulas dos cereais. Quando os frangos foram alimentados com raça triturada-granulada com os ingredientes com granulametria fina ou grosseira, os pesos corporais foram equivalentes, indicando que a granulaço e a trituraçào uniformizaram a raçăo. 
Apesar do crescimento extra e melhora na conversao alimentar associada a alimentaça nas formas triturada ou granulada, os autores concluiram que esta pratica nas fases inicial e crescimento năo apresentaram vantagem do ponto de vista económico no sentido de mascarar a moagem grosseira dos grăos, previnindo a separaça dos ingredientes e evitando a ocorrencia de microrganismos, uma vez que nå foi encontrada diferença no retorno económico entre as dietas, exceto para raçao farelada com milho e trigo moidos finos, ande o retarno foi significativamente menor. 
3. Material e Metodos

\subsection{Instalaçøes e Equipamentos Experimentais}

0 experimento foi conduzido no aviário experimental do Departamento de Zootecnia da Escola Superior de Agricultura "Luiz de Queiroz" da Universidade de Sao Paulo, "Campus" de Piracicaba, no periodo compreendido entre 1 de junho a 13 de julho de 1989.

o aviário experimental possui dimensobes de 32 por $8 \mathrm{~m}$, com mureta lateral de alvenaria de tijolos de $0,6 \mathrm{~m}$ de altura e completada com tela de arame de $1 / 2 \times$ $3 / 4$ de polegada de malha, com piso de concreto. Os lados com tela do galinheiro sao providos de cortinado de polietileno que se fecha de baixo para cima.

0 aviário é constituido de três fileiras com 10 divisoes cada, com portas que se abrem para os corredores de $1,0 \mathrm{~m}$ de largura. As divisoes de criaçao possuem dimensdes de $2,5 \times 2,0 \mathrm{~m}$ e 5 ao separadas por tábuas de $0,3 \mathrm{~m}$ de altura e completadas por tela de arame de 2 polegadas de malha ate a altura de $2,0 \mathrm{~m}$. O aviario possui também uma area de $3,5 \times 8,0 \mathrm{~m}$ de cada lado para armazenamento das raçôes experimentais e equipamentos onde se realiza a pesagem cas aves.

A iluminaçao artificial foi realizada por meio de 11 lampadas de 60 watts cada, dispostas no sentido longitudinal e central da instalaça, suspensas a altura de $2,3 \mathrm{~m}$ do piso.

Para cada divisaa foi utilizado um comedouro tipo bandeja de $0,30 \times 0,50 \mathrm{~m}$ nos 13 primeiros dias 
de idade das aves e do nono dia até o final do experimento foram utilizados comedouros tubulares suspensos. No periodo de 9 a 13 dias de idade permaneceram os dois tipos de comedouras nas divisoles para que as aves se adaptassem ao tubular suspenso. Os bebedouros utilizados durante todo o periodo experimental foram do tipo pendular.

A "cama" utilizada foi de cavaco de madei$\mathrm{ra}$, com espessura media de $4,0 \mathrm{~cm}$.

0 aquecimento inicial dos pintos foi feito com uma lâmpada de 250 watts, suspensa a $0,60 \mathrm{~m}$ do piso, em cada divisăo de criaçăo, a qual permaneceu acesa por 24 horas diarias ate que as aves completassem 21 dias de idade. Dai em diante, as lampadas eram ligadas apenas a noite, sendo retiradas definitivamente quando as aves completaram 28 dias de idade.

\subsection{Periodo Experimental}

- periodo experimental compreendeu do primeiro ao quadragésimo segundo dia de idade. O programa de alimentaçăo constituiu de raçăo única do inicio ao final do experimento.

\subsection{Aves experimentais}

Foram utilizados 900 pintos de corte machos da Iinhagem Hubbard, autosexáveis pelas penas das asas e vacinados contra doença de Marek, provenientes da Gr,anja Santo Antonio em Rio Claro, Estado de Sao Paulo.

\subsection{Manejo das aves}

Qs pintos de um dia foram distribuidos em 30 divisoes de 30 pintos cada, previamente aquecidas por 
lâmpadas que permaneceram acesas até os 28 dias de idade, devido as baixas temperaturas registradas no periodo experimental. As lampadas de iluminaça permaneceram Iigadas somente a noite após a retirada das lampadas de aquecimento.

As aves foram vacinadas contra doença de New-Castle aos 9 dias de idade pela água de beber.

\subsection{Composiçăo das Raçôes Experimentais.}

As dietas foram a base de milho, farelo de soja e farinha de carne e ossos, suplementada com minerais, vitaminas, calcario e sal moido. Do ponto de vista rutricional as raçôes nao apresentavam diferenças, variando somente quanto a granulometria do milho e a forma da raça. 0 milho foi moido utilizando-se moinho de martelo com peneiras de crivos $4,0,8,0$ e $12,0 \mathrm{~mm}$, e incorporado a raçăo a qual foi fornecida nas formas farelada e triturada. A escoliha da forma triturada, em lugar da forma granulada se deve ao fato de termos utilizado uma raça única em todo - periodo experimental.

Os tratamentos utilizados no experimento foram:

T1-Rạ̧ăo farelada contendo milho moido na peneira $4 \mathrm{~mm}$; T2-Raçăo triturada contendo milho moido na peneira $4 \mathrm{~mm}$; T3-Raçăo farelada contendo milho moido na peneira $8 \mathrm{~mm}$; T4-Raçao triturada contendo milho moido na peneira $8 \mathrm{~mm}$; T5-Raça farelada contendo milho moido na peneira $12 \mathrm{~mm}$; To-Raçăo triturada contendo milho moido na peneira $12 \mathrm{~mm}$.

Foram feitas análises quimica, bromatologica e granulometrica dos ingredientes utilizados nas raçoes experimentais (tabelas 1,2 e 3 ) e das raçoes experimentais 
(tabela b) nos laboratorios da SUPRE MAIS/BLM, em Valinhos, Estado de Sao Paulo.

Tabela 1. Resultados de análise do farelo de soja tostado utilizado nas raçoes experimentais.

Proteina bruta (\%) $\quad 45,71$

Solubilidade do nitrogênio (\%) 86,46

Atividade ureática 0,05

Tabela 2. Resultados de análise da farinha de carne e ossos utilizada nas raçoes experimentais.

\begin{tabular}{lc}
\hline Umidade (vol.105c),(\%) & 4,57 \\
Acidez livre $(\mathrm{ml}),(\%)$ & 2,71 \\
Teste de Eber & neg. \\
Teste de Kreiss & pos. \\
Indice de perdxido,(meq) & 28,85 \\
Proteina bruta, $(\%)$ & 38,97 \\
Extrato etereo, $(\%)$ & 12,30 \\
Materia mineral, $(\%)$ & 42,37 \\
Calcio, $(\%)$ & 14,04 \\
Fosforo total, $(\%)$ & 7,23 \\
\hline
\end{tabular}


Tabela 3. Resultados de análise das granulometrias do milho utilizado nas raçøes experimentais.

$\begin{array}{lllll}\text { Granulometria }(\mathrm{mm}) & 4 & 8 & 12\end{array}$

$\begin{array}{llrrr}\text { Retido na peneira } 8 \text { mesh (\%) } & 2,8 & 14,1 & 22,6 \\ \text { Retido na peneira } 24 \text { mesh (\%) } 71,9 & 71,5 & 56,6 \\ \text { Retido na peneira } 42 \text { mesh (\%) } 13,8 & 8,3 & 10,7 \\ \text { Passados (\%) } & & 11,5 & 6,1 & 10,1\end{array}$

As raçoes foram formuladas utilizando-se a técnica de programaço linear no computador da SUPRE MAIS/BLM. A mistura dos ingredientes fai feita nas instalaçbes das Raçôes Ceres S.A. em Piracicaba, Estado de Sao Paulo. A composiçăo centesimal dos ingredientes é apresentada na tabela 4 e a composiça nutritiva na tabela 5. 
Tabela 4. Composiçăo centesimal da raçăo experimental.

Ingredientes $(\%)$

Milho moido 63,3

Farelo de soja tostado 30,3

Farinha de carne e ossos

5,1

Calcáreo calcitico

0,5

Sal moido

0,3

Suplemento mineral (1)

0,1

Suplemento vitaminico e aditivos (2)

0,4

Total 100,0

(1) Composiçao por quilograma do suplemento mineral: Manganês, $65.000 \mathrm{mg}$; Zinco, $50.000 \mathrm{mg}$;Ferro, $40.000 \mathrm{mg}$; Cobre $12.000 \mathrm{mg}$; Iodo $1.000 \mathrm{mg}$; e veiculo, q.5.p $1.000 \mathrm{~g}$ (2) Composiçăo por quilograma do suplemento vitaminico: vitamina A, 1.750.000 U.I; vitamina D3, 500.000 U.I; vitamina E, $2.750 \mathrm{mg}$; vitamina $K 3$, $500 \mathrm{mg}$; vitamina $B 1,500$ mg; vitamina B2, $1.250 \mathrm{mg}$; Vitamina B6, $700 \mathrm{mg}$; vitamina B12, $2.500 \mathrm{mcg}$ acido fólico, $200 \mathrm{mg}$; pantotenato de cálcio, $3.000 \mathrm{mg}$; niacina, $7.000 \mathrm{mg}$; antioxidante (BHT), $25 \mathrm{mg}$; agente anticoccidiano (Coxistac1-salinomicina sodica 609 por kg do produto), $250 \mathrm{~g}$; promotor de crescimento (Nitrovin-98,5\%), 25 . g; cloreto de colina, 150 g; DL-metionina, $300 \mathrm{~g}$; selênio, $50 \mathrm{mg}$; e veiculo q.5.P 1.000 g.

2 Produto PFIZER. 
Tabela 5. Composiça nutritiva calculada da raça experimental.

\begin{tabular}{lr}
\hline Especificaçose & Calculada \\
\hline Energia met.,kcal/kg & $2.925,00$ \\
Proteina bruta, $(\%)$ & 21,50 \\
Materia fibrosa, $(\%)$ & 3,29 \\
Extrato etereo, $(\%)$ & 3,90 \\
Materia mineral, $(\%)$ & 5,08 \\
Calcio, $(\%)$ & 0,99 \\
Fosforo disponivel, (\%) & 0,44 \\
Metionina, $(\%)$ & 0,46 \\
Cistina, $(\%)$ & 0,32 \\
Met-cis, $(\%)$ & 0,78 \\
Lisina, $(\%)$ & 1,11 \\
Triptofano, $(\%)$ & 0,27 \\
\hline
\end{tabular}

As análises bromatologicas e granulometricas das raçoes utilizadas se encontram nas tabelas 6 e 7 . 
Tabela 6. Resultados das analises bromatologicas e granulometricas das raçôes experimentais.

Resul tados

Análises efetuadas

T1

T2

T3

Granulometria

Retido na peneira 10 mesh

$$
9,5
$$

18,9

8,5

Retido na peneira 20 mesh

48,9

52,8

46,6

Retido na peneira 30 mesh

10,0

5,9

12,1

Retido na peneira 50 mesh

24,6

16,8

23,6

Passados ma peneira 50 mesh

7,0

5,6

9,2

Umidade (vol 105 oc), (\%)

11,8

12,1

11,9

Proteina bruta, (\%)

19,0

18,9

18,6

Calcio, (\%)

1,0

1,1

1,0

Fosforo total, $(\%)$

0,6

0,6

0,6 
(continuaça)

Resultados

Análises efetuadas

T4

T5

T6

Granulometria

Retido na peneira 10 mesh

Retido na peneira 20 mesh

Retido na peneira 30 mesh

Retido na peneira 50 mesh

Passados na peneira 50 mesh

Umidade (vol 105 oc), (\%)

Proteina bruta, $(\%)$

Cálcio, (\%)

Fosforo total, (\%)

$\begin{array}{rrc}20,2 & 22,2 & 18,0 \\ 45,0 & 43,6 & 46,0 \\ 7,6 & 7,5 & 10,1 \\ 17,8 & 16,8 & 20,8 \\ 9,4 & 9,9 & 5,1 \\ 12,0 & 11,9 & 11,9 \\ 20,2 & 20,8 & 18,8 \\ 1,1 & 1,2 & 1,3 \\ 0,7 & 0,7 & 0,6\end{array}$

3.6. Qbtença de dados

3.6.1. Temperatura Ambiente

As temperaturas foram obtidas durante o periodo experimental por meio de dois termômetros de máxima e minima dispostos um na lateral NE e outro na lateral $\mathrm{SW}$ do galinheiro e a altura de 0,3 metros do piso. As leituras foram registradas diariamente as 8:45 horas. (Apêndice 1)

\subsubsection{Peso Corporal}

As pesagens foram efetuadas no primeiro dia e semanalmente até 42 dias de idade das aves. As quatro primeiras pesagens foram feitas em balança de prato com capacidade de $20 \mathrm{~kg}$ e precisao de $0,01 \mathrm{~kg}$ e as três últimas pesagens em balança de plataforma com capacidade de $150 \mathrm{~kg}$, 
e precisao de $0,5 \mathrm{~kg}$. As aves foram pesadas em conjunto por parcela.(Apendice 2 e 3 )

\subsubsection{Consumo de Raçao}

Foram feitos dois tipos de controle quanto ao consumo de raça. Um controle diário com apenas uma divisao por tratamento, a fim de se acompanhar melhor o experimento e um controle semanal nos dias de pesagens das aves, onde todos os comedouros foram pesados. (Apêndice 4 e 5)

\subsubsection{Mortalidade e Refugagem}

A mortalidade das aves foi registrada no dia de ocorrência, sendo as mesmas pesadas tao logo fossem encontradas mortas. Nos primeiros quatro dias do experimento, as aves mortas foram substituidas.

A refugagem foi feita a medida que se observou problemas de pernas, ascite e reduça no ganho de peso. (Apêndice 6)

3.6.5. Ganho de Peso e Conversao Alimentar

- ganho de peso foi calculado semanalmente, durante todo periodo experimental pela diferença do peso medio de uma semana para outra.

A conversao alimentar foi determinada para cada parcela experimental no final do experimento e por periodos. Os calculos. das conversoes alimentares foram feitos levando-se em.consideraça os pesos corporais das aves mortas e refugadas nos periodos considerados. 
3.7. Delineamento Experimental

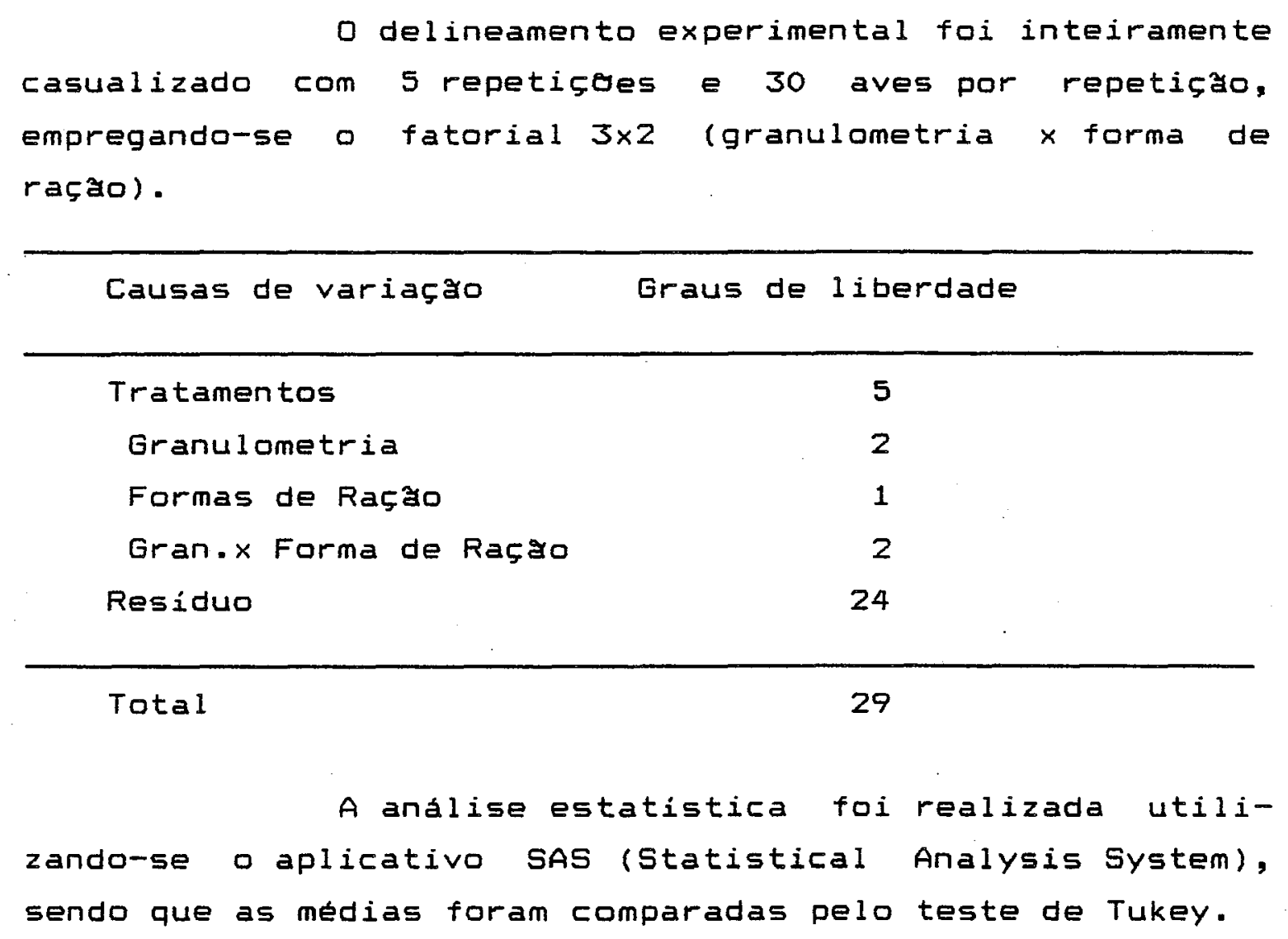


4. RESULTADOS E DISCUSSÃo

4.1. Análise de Variancia

4.1.1. Peso Médio das Aves

Os resultados da análise de variancia do peso médio das aves aos $7,14,21,28,35$ e 42 dias de idade se encontram nos tabelas 7, 8, 9, 10, 11 e 12 .

TABELA 7. Análise de variancia do peso médio das aves aos 7 dias de idade.

Causas de variaça $\quad G L \quad Q M \quad F \quad$ Prob>F

\begin{tabular}{lrrrr}
\hline Granulometria(1) & 2 & 89,84 & 5,67 & $0,0096^{*}$ \\
Forma de raça(2) & 1 & 39,44 & 2,49 & 0,1277 \\
(1) x (2) & 2 & 8,90 & 0,56 & 0,5773 \\
Residuo & 24 & 15,84 & & \\
\hline
\end{tabular}

Total 29

* Significativo ao nivel indicado. Média geral : $131,94 \mathrm{~g}$.

Coeficiente de variaçăo: $3,01 \%$ 
TABELA 8. Análise de variancia do peso medio das aves aos 14 dias de idade.

Causas de variaçao

GL

$\mathrm{QM}$

F. Prob>F

Granulometria(1)

$\begin{array}{llll}2 & 800,44 & 8,82 & 0,0013^{*} \\ 1 & 931,86 & 10,27 & 0,0038^{*} \\ 2 & 89,84 & 0,99 & 0,3863 \\ 24 & 90,77 & & \end{array}$

(1) $\times(2)$

2490,77

Total 29

* Significativo ao nivel indicado.

Media geral : $323,48 \mathrm{~g}$.

Coeficiente de variaça : $2,94 \%$

TABELA 9. Análise de variancia do peso medio das aves aos 21 dias de idade

\begin{tabular}{|c|c|c|c|c|}
\hline Causas de variaçao & GL & QM & $F$ & Prob>F \\
\hline Granulometria(1) & 2 & 2353,45 & 10,33 & $0,0006^{*}$ \\
\hline Forma de raçao(z) & 1 & 2217,08 & 9,73 & $0,0047^{*}$ \\
\hline$(1) \times(2)$ & 2 & 151,54 & 0,67 & 0,5325 \\
\hline Residuo & 24 & 227,88 & & \\
\hline Total & 29 & & & \\
\hline $\begin{array}{l}\text { * Significativo ao nivel } \\
\text { Media geral : } 633,95 \mathrm{~g} \text {. } \\
\text { Coeficiente de variaça }\end{array}$ & ind & icado. & & \\
\hline
\end{tabular}


TABELA 10. Análise de variancia do peso medio das aves aos 28 dias de idade

\begin{tabular}{lrrrr}
\hline Causas de variaçao & GL & QM & $F$ & Prob>F \\
\hline Granulometria(1) & 2 & 1886,27 & 4,28 & $0,0257^{*}$ \\
Forma de raçao(2) & 1 & 2641,40 & 6,00 & $0,0220^{*}$ \\
(1) $\times(2)$ & 2 & 1076,49 & 2,44 & 0,1081 \\
Residuo & 24 & 440,50 & &
\end{tabular}

Total 29

* Significativo ao nivel indicado. Media geral : $1039,36 \mathrm{~g}$.

Coeficiente de variaçăo: $2,02 \%$

TABELA 11. Análise de variancia do peso medio das aves aos 35 dias de idade.

$\begin{array}{lllll}\text { Causas de variaça } & \text { GL } & \text { QM } & F & \text { Prob>F }\end{array}$

\begin{tabular}{lrrrr}
\hline Granulametria(1) & 2 & 2383,15 & 4,40 & $0,0236 *$ \\
Forma de raça(2) & 1 & 6970,77 & 12,87 & $0,0015^{*}$ \\
(1) x (2) & 2 & 1362,06 & 2,51 & 0,1020 \\
Residuo & 24 & & &
\end{tabular}

Total

29

* Significativo ao nivel indicado.

Media geral : 1482,439 .

Coeficiente de variaçă : $1,56 \%$ 
TABELA 12. Análise de variância do peso medio das aves aos 42 dias de idade.

\begin{tabular}{llrrrr}
\hline Causas de variaçao & GL & QM & $F$ & Prob>F \\
\hline Granulometria(1) & 2 & 641,69 & 0,60 & 0,5561 \\
Forma de raça(2) & 1 & 15778,13 & 14,79 & $0,0008 *$ \\
$(1) \times(2)$ & 2 & 3429,61 & 3,21 & 0,0579 \\
Residuo & 24 & 1066,79 & & \\
\hline
\end{tabular}

Tota 1 29

* Significativo ao nivel indicado.

Média geral : $1998,57 \mathrm{~g}$.

Coeficiente de variaça : $1,63 \%$

Observa-se pelas tabelas de análise de variancia do peso medio das aves que a interaçăo forma de raçăo e granulometria do milho năo foi significativa em nenhuma das idades. Houve efeito significativo da forma de raçao ( $P<0,05$ ) sobre 0 peso medio das aves nas idades de $14,21,28,35$ e 42 dias e efeito significativo da granulometria do milho ( $P<0.05$ ) aos $7,14,21,28$ e 35 dias de idade. 
4.1.2. Ganho de Peso das Aves

Us resultados da análise de variância do ganho de peso médio das aves na primeira, segunda, terceira, quarta, quinta e sexta semanas de idade das aves encontram-se nas tabelas 13, 14, 15, 16, 17 e 18 .

TABELA 13. Análise de variância do ganho de peso medio das aves durante a primeira semana de idade.

\begin{tabular}{llrll}
\hline Causas de variaço & GL & QM & $F$ & Prob>F \\
\hline Granulometria(1) & 2 & 104,31 & 6,59 & $0,0052 *$ \\
Forma de raçao(2) & 1 & 44,89 & 2,84 & 0,1052 \\
$(1) \times(2)$ & 2 & 7,66 & 0,48 & 0,6220 \\
Residuo & 24 & 15,83 & & \\
\hline
\end{tabular}

Total 29

* Significativo ao nivel indicado.

Média geral : $88,44 \mathrm{~g}$.

Coeficiente de variaçă : $4,49 \%$ 
TABELA 14. Análise de variância do ganho de peso medio das aves durante a segunda semana de idade.

\begin{tabular}{llcrl}
\hline Causas de variaçao & GL & QM & $F$ & Prob>F \\
\hline Granulometria(1) & 2 & 352,84 & 8,40 & $0,0017^{*}$ \\
Forma de raçăo(2) & 1 & 590,52 & 14,07 & $0,0010^{*}$ \\
(1) $\times(2)$ & 2 & 129,16 & 3,08 & 0,0646 \\
Residuo & 24 & 41,98 & & \\
\hline
\end{tabular}

Total 29

* Significativo ao nivel indicado. Média geral : $191,53 \mathrm{~g}$.

Coeficiente de variaçă: $3,38 \%$

TABELA 15. Análise de variancia do ganho de peso médio das aves durante a terceira semana de idade.

Causas de variaçåo GL $Q M$ G

\begin{tabular}{llrll}
\hline Granulometria(1) & 2 & 409,37 & 6,96 & $0,0041^{*}$ \\
Forma de racao(2) & 1 & 270,60 & 4,60 & $0,0422^{*}$ \\
$(1) \times(2)$ & 2 & 48,85 & 0,83 & 0,4477 \\
Residuo & 24 & 58,78 & & \\
\hline
\end{tabular}

Total 29

* Significativo ao nivel indicado. Média geral : $310,46 \mathrm{~g}$. Coeficiente de variaçă: $2,47 \%$ 
TABELA 16. Análise de variancia do ganho de peso medio das aves durante a quarta semana de idade.

\begin{tabular}{lllll}
\hline Causas de variaça & GL & QM & $F$ & Prob>F \\
\hline Granulometria(1) & 2 & 27,18 & 0,14 & 0,8734 \\
Forma de raçă(2) & 1 & 19,52 & 0,10 & 0,7572 \\
(1) $\times(2)$ & 2 & 422,84 & 2,12 & 0,1423 \\
Residuo & 24 & 199,69 & &
\end{tabular}

Total

Média geral : $405,41 \mathrm{~g}$.

Coeficiente de variaçao: $3,48 \%$

TABELA 17. Análise de variancia do ganho de peso medio das aves durante a quinta semana de idade.

\begin{tabular}{lcccc}
\hline Causas de variaçao & GL & GM & $F$ & Prob>F \\
\hline Granulometria(1) & 2 & 84,88 & 0,14 & 0,8689 \\
Forma de raçăo(2) & 1 & 522,50 & 0,87 & 0,3602 \\
(1) X (2) & 2 & 432,31 & 0,72 & 0,4969 \\
Residuo & 24 & 600,34 & & \\
\hline Total & & & & \\
\hline
\end{tabular}

Media geral : 444,76 9 .

Coeficiente de variaça : $5,50 \%$ 
TABELA 18. Análise de variancia do ganto de peso medio das aves durante a segunda semana de idade.

Causas de variaçăo GL QM $F \quad$ Prob>F

Granulometria(1)

Forma de raçă(2)

(1) $\times(2)$

Residuo

$\begin{array}{rrrr}2 & 737,29 & 1,75 & 0,1958 \\ 1 & 1731,284,10 & 0,0541 \\ 2 & 731,711,73 & 0,1981 \\ 24 & 422,10 & & \end{array}$

29

Média geral : $516,04 \mathrm{~g}$.

Coeficiente de variaçăo: $3,98 \%$

Igualmente para o observado no peso médio - ganho de peso, tambem não apresentou interaçăo significativa entre os fatores forma de raçao e granulometria do milho em todas as semanas. Houve efeito significativo $(P<0,05)$ da forma de raçăo na segunda e terceira semanas, assim como o fator granulometria do. milho que alem da segunda e terceira semanas, apresentou resultado significativo ( $P<0,05)$ na primeira semana.

\subsubsection{Conversão Alimentar das Aves}

Os resultados da análise de variancia da conversao alimentar das aves nos periodos de 1 a 7,1 a 14, 1 a 21,1 a 28, 1 a 35,1 a 42 dias de idade das aves encontram-se nas tabelas 19, 20, 21, 22, 23 e 24 . 
TABELA 19. Análise de variancia da conversao alimentar das aves no periodo de 1 a 7 dias de idade.

Causas de variaçå

GL $Q M \quad F \quad$ Prob>F

Granulometria(1)

Forma de raçao(2)

(1) $\times$ (2)

Residuo

$\begin{array}{llll}2 & 0,0057 & 3,92 & 0,0367 * \\ 1 & 0,0055 & 3,80 & 0,0594 \\ 2 & 0,0000 & 0,00 & 0,9971 \\ 24 & 0,0014 & & \end{array}$

29

Total

* Significativo ao nivel indicado.

Media geral : 1,26

Coeficiente de variaçåo: $3,02 \%$

TABELA 20. Análise de variância da conversao alimentar das aves no periodo de 1 a 14 dias de idade.

\begin{tabular}{lllll}
\hline Causas de variaçao & GL & QM & $F$ & Prob>F \\
\hline Granulometria(1) & 2 & 0,0085 & 3,10 & 0,0635 \\
Forma de raçao(2) & 1 & 0,0545 & 19,69 & $0,0002^{*}$ \\
(1) $\times(2)$ & 2 & 0,0043 & 1,56 & 0,2301 \\
Residuo & 24 & 0,027 & & \\
\hline Total & & & & \\
\hline
\end{tabular}

* Significativo ao nivel indicado.

Média geral : 1,53

Coeficiente de variação: $3,44 \%$ 
TABELA 21. Análise de variancia da conversão alimentar das aves no periodo de 1 a 21 dias de idade.

\begin{tabular}{lllll}
\hline Causas de variaça & GL & QM & $F$ & Prob>F \\
\hline Granulometria(1) & 2 & 0,0020 & 1,12 & 0,3433 \\
Forma de raçao(2) & 1 & 0,0257 & 13,87 & $0,0011^{*}$ \\
(1) X (2) & 2 & 0,0004 & 0,23 & 0,7974 \\
Residuo & 24 & 0,0018 & & \\
\hline Total & 29 & & &
\end{tabular}

* Significativo ao nivel indicado.

Média geral : 1 , t6

Coeficiente de variação: $2,59 \%$

TABELA 22. Análise de variancia da conversao alimentar das aves no periodo de 1 a 28 dias de idade.

Causas de variaço GL $Q M \quad F \quad$ Prob>F

$\begin{array}{lllrl}\text { Granulometria(1) } & 2 & 0,0021 & 1,82 & 0,1836 \\ \text { Forma de raça(2) } & 1 & 0,0233 & 20,26 & 0,0001^{*} \\ \text { (1) } \times(2) & 2 & 0,0006 & 0,57 & 0,5711 \\ \text { Residuo } & 24 & 0,0011 & & \end{array}$

Total 29

* Significativo ao nivel indicado.

Media geral : 1,80

Coeficiente de variaçăo : $1,88 \%$ 
TABELA 23. Análise de variancia da conversăo alimentar das aves no periodo de 1 a 35 dias de idade.

\begin{tabular}{llclll}
\hline Causas de variaça & GL & QM & $F$ & Prob>F \\
\hline Granulometria(1) & 2 & 0,0035 & 7,11 & $0,0038^{*}$ \\
Forma de raçao(2) & 1 & 0,0122 & 24,48 & $0,0001^{*}$ \\
$(1) \times(2)$ & 2 & 0,0001 & 0,17 & 0,0439 \\
Residuo & 24 & 0,0004 & &
\end{tabular}

Total 29

* Significativo ao nivel indicado. Média geral : 1,95

Coeficiente de variaçăo : $1,14 \%$

TABELA 24. Analise de variancia da conversao alimentar das aves no periodo de 1 a 42 dias de idade.

\begin{tabular}{llllll}
\hline Causas de variaçao & GL & QM & $F$ & Prob>F \\
\hline Granulometria(1) & 2 & 0,0044 & 3,76 & $0,0381 *$ \\
Forma de raça(2) & 1 & 0,0151 & 12,69 & $0,0016 *$ \\
$(1) \times(2)$ & 2 & 0,0007 & 0,63 & 0,5432
\end{tabular}

Residuo $24 \quad 0,0012$

Total 29

* Significativo ao nivel indicado.

Média geral: 2,063

Coeficiente de variaça: $1,67 \%$

Neste caso tambem, a interaça forma de raça e granulometria do milho năo foi significativa em nenhum dos pefídos analisados. O fator forma de raçao teve efeito significativo $(P<0,05)$ em todos os periodos estudados, exceto de 1 a 7 dias de idade. O fator granu- 
lometria do milho teve efeito significativo ( $P<0,05$ ) nos periodos de 1 a 7,1 a 14,1 a 35 e 1 a 42 dias.

4.2. Forma de Raçăo

Como foi constatado anteriormente, em nenhum dos parâmetros analisados houve interaçao entre os fatores forma de raçăo granulometria do milho.

Os resultados de peso medio, ganho de peso medio e conversao alimentar das aves encontram-se nas tabelas 25, 26, 27, 28, 29, 30 e 31 .

Tabela 25. Peso medio das aves segundo o fator forma de $\operatorname{raçao~}(7,14$ e 21 dias $)$.

\begin{tabular}{lccc}
\hline Formas de & \multicolumn{3}{c}{ Idade (dias) } \\
Raçao & 7 & 14 & 21 \\
& & & \\
\hline Farelada & $130,79 a$ & $312,91 a$ & $625,35 a$ \\
Triturada & $133,08 a$ & $329,06 \mathrm{~b}$ & $642,54 \mathrm{~b}$
\end{tabular}

As medias seguidas por letras distintas na mesma coluna diferem entre $s i$ ao nivel de $5 \%$

Tabela 26. Peso médio das aves segundo o fator forma de raçăo ( 28,35 e 42 dias).

\begin{tabular}{lccc}
\hline Formas de & \multicolumn{3}{c}{ Idade (dias) } \\
Paçao & 28 & 35 & 42 \\
& & & \\
\hline Farelada & $1029,98 a$ & $1467,18 a$ & $1975,64 a$ \\
Triturada & $1048,74 b$ & $1497,74 b$ & $2021,57 b$
\end{tabular}

As medias seguidas por letras distintas na mesma
coluna diferem entre $5 i$ ao nivel de $5 \%$


Tabela 27. Ganho de peso medio das aves segundo o fator forma de raçao (primeira, segunda e terceira semanas de idade).

\begin{tabular}{lccc}
\hline Formas de & \multicolumn{3}{c}{ Semanas } \\
Raçao & 1 & 2 & 3 \\
\hline Farelada & & & \\
Triturada & $87,22 a$ & $187,10 a$ & $307,46 a$ \\
& $89,66 a$ & $195,97 \mathrm{~b}$ & $313,46 \mathrm{~b}$
\end{tabular}

As medias seguidas por letras distintas na mesma coluna diferem entre $s i$ ao nivel de $5 \%$

Tabela 28: Ganho de peso médio das aves segundo o fator forma de raçao ( quarta, quinta e sexta semanas de idade).

Formas de

Rạ̧ao

Farelada

Triturada
Semanas

4

$404,60 a$

$406,22 a$
5

$440,59 a$

$448,94 a \quad 523,64 a$

6

As médias seguidas por letras distintas na mesma coluna diferem entre si ao nivel de $5 \%$. 
Tabela 29. Conversao alimentar das aves segundo o fator forma de raçao (1-7, 1-14 e 1-21 dias).

\begin{tabular}{lccc}
\hline $\begin{array}{l}\text { Formas de } \\
\text { Raço }\end{array}$ & \multicolumn{4}{c}{ Periodos (dias) } \\
& $1-7$ & $1-14$ & $1-21$ \\
\hline Farelada & $1,279 a$ & $1,569 a$ & $1,691 \mathrm{a}$ \\
Triturada & $1,251 \mathrm{a}$ & $1,484 \mathrm{~b}$ & $1,632 \mathrm{~b}$
\end{tabular}

As médias seguidas por letras distintas na mesma coluna diferem entre $s i$ ao nivel de $5 \%$

Tabela 30. Conversao alimentar das aves segundo o fator forma de raço (1-28,1-35 e 1-42 dias).

\begin{tabular}{lcrc}
\hline $\begin{array}{l}\text { Formas de } \\
\text { Rạă }\end{array}$ & \multicolumn{3}{c}{ Periodos (dias) } \\
& $1-28$ & $1-35$ & $1-42$ \\
\hline Farelada & $1,829 a$ & $1,971 a$ & $2,086 a$ \\
Triturada & $1,773 b$ & $1,931 b$ & $2,041 b$
\end{tabular}

As medias seguidas por letras distintas na mesma coluna diferem entre $s i$ ao nivel de $5 \%$.

Muitos pesquisadores apontam as vantagens do uso de raçă nas formas granulada e triturada (HEYWANG \& MORGAN, 1944; BEARSE et alii, 1952; LANSON \& SMYTH, 1955; ALLRED et alii, 1957 ; PEPPER et alii, 1960; HUSSAR \& ROBLEE, 1962; BAYLEY et alii, 1968; AUCKLAND \& FULTON, 1971; PROUDFOOT \& SEFTON, 1978; ZELENKA \& SIROKY, 1979; WENK \& ES, 1980; BRUE \& LATSHAW, 1981; SOUZA et alii, 1982; REECE et alii, 1984; CHOI et alii, 1986 e BERTECHINNI, 1987) e outros encontraram resultados negativos (ELEY \& BELL, 1948 e STEWART \& UPP, 1951). 
As respostas para a melhora no desempenho das aves com o uso de raça nas formas granulada e triturada năo estå bem definidas. Săo apontadas várias vantagens destas formas : destruiça de fatores toxicos inibidores do crescimento, aumento da energia metabolizavel da ração, reduçăo do desperdicio de raçăo, melhorando a digestibilidade pela gelatinizaçăo do amido, destruiçăo de microrganismos patogênicos presentes no alimento pela açăo do calor envolvido no processo, diminuiça da segregaça das particulas por parte das aves e a diminuicăo no tempo gasto para se alimentar, poupando assim energia para as aves. Quanto as desvantagens do uso destas formas de raça săo : a destruiça de aminoacidos, vitaminas e antibidticos devido à temperatura e pressao envolvidos no processo, o alto custo do equipamento, a aumento na incidencia de canibalismo devido ao menor tempo gasto pelas aves para se alimentarem e o maior consumo de água, possibilitando o aumento da umidade da "cama".

Nas tabelas 25 e 26, observamos que as aves alimentadas com raçăo triturada apresentaram resultados de peso médio significativamente maiores $(P<0,05)$ a partir da segunda semana de idade, resultados estes que diferem dos encontrados por STEWART \& UPP (1951), quando as aves eram criadas ate 12 semanas de idade, onde a taxa de crescimento e a eficiência alimentar năo foram muito afetadas pela forma de raça. ALLRED et alli (1957a) trabalharam com dietas nas formas triturada e farelada e encontraram aos 28 dias de idade resultados significativamente melhores $(P<=0,01)$ quanto ao ganho de peso e conversao alimentar com 0 uso de raçao triturada comparada a farelada.

JENSEN (1956) atribuil esta melhora nos resultados com o uso de raçao granulada e triturada a um aumento na disponibilidade da proteina e à destruicăo de fatores inibidores do crescimento. ALLRED et alii(1957b), 
também atribuiram esta melhora à inativaça de fatores inibidores do crescimento, sendo que o milho foi o único ingrediente afetado pela granulaçao, isto é, que determinou melhora no desempenho das aves.

BOLTON (1960), aporita a melhora na palatabilidade, o aumento na densidade do alimento, a quebra de componentes dos alimentos pelo calor e a destruiçao dos fatores inibidores do crescimento como determinantes na melhora do desempenho das aves com o uso de raçao granulada ou triturada, uma vez que nao encontrou diferença na digestibilidade da proteina, do bleo e dos carboidratos entre as duas formas de raçăo estudadas a farelada e a granulada.

AUCKLAND \& FULTON (1972b) tambem encontraram melhores resultados com $\circ$ uso de raça triturada, devido ao menor gasto de tempo e energia por parte das aves para se alimentarem.

Quanto a energia metabolizável das raçôes nas diferentes formas, os resultados sao conflitantes. REDDY et alii (1962) encontraram diferença entre. as energias das raçòes farelada e triturada, enquanto que SIBBALD (1979) nào encontrou diferença significativa $(P>0,05)$ entre a energia metabolizável das raçoes farelada, triturada e granulada.

As raçoes triturada e granulada apresentam um efeito economizador de energia, devido a um aumento na eficiēncia alimentar. Segundo BERTECHINNI (1987), os efeitos da granulaça foram diminuindo a medida que aumentavam os niveis de energia, sugerindo que as maiores beneficios do uso da forma granulada sao observados em dietas com menor densidade calórica.

Na tabela 28, observamos que o ganho de peso medio semanal foi numericamente e ou estatisticamente maior para a forma triturada de raça, indicando 
que as aves nao apresentaram dificuldades en se alimentarem com esta forma, mesmo no periodo inicial.

Dutros fatores relacionados com o uso das formas triturada e granulada da raço é a maior incidência de sindrome da morte súbita, ascite e problemas de perna. PROUDFOOT et alii (1982), encontraram um maior indice de mortalidade devido ao aumento na incidência da sindrome da morte súbita, e relacionaram este fato a fatores nao identificados que surgem do processo de granulaçăo e năo ao rápido crescimento, uma vez que as aves alimentadas com raça triturada inicial e granulada final tiveram crescimento similar ao das aves que receberam raça na forma farelada, mas o indice de mortalidade foi maior no tratamento triturada-granulada. PROUDFOOT \& HULAN (1982a) concluiram que se descoberto o fator que surge com a granulaçăo que determina o aumento da mortalidade, 0 uso de rạăo na formas triturada e granulada continua sendo recomendavel do ponto de vista biologico e econômico.

SILVA et alii (1988), trabalharam com raçăo granulada relacionada a incidência de ascite. A raço na forma granulada foi fornecida desde a primeiro dia de idade das aves. Neste experimento a incidência de ascite foi muito baixa para permitir conclusoes definitivas, mas qualquer fator que acelere.o crescimento das aves contribuira para um aumento na incidencia de ascite. - uso de raça nas formas granulada e triturada năo apresentou resultados satisfatorios para aves pesadas, HULAN \& PROUDFOOT (1987) constataram pior conversao alimentar, maior incidencia de problemas de pernas e da sindrome da morte súbita com o uso de raça granulada para aves pesadas, e recomendam o uso da forma farelada em todos as periodos.

Nas tabelas 29 e 30 , observamos que as conversoles alimentares foram significativamente melhores 
para as aves alimentadas com raça triturada em todos os periodos. MCNAUGHTON \& REECE (1984), encontraram tambem melhores resultados de conversao alimentar no periodo de 1 a 28 dias de idade das aves com o uso de raçao na forma triturada. REECE et alii (1984) encontraram diferença significativa $(P<0,05)$ entre as conversoes alimentares das raçôs farelada e triturada aos 45 dias de idade, sendo que a melhor conversăo alimentar foi conseguida com - uso de raçăo triturada.

As vantagens apresentadas pela granulaçăo e trituraçăo as inúmeros trabalhos com resultados positivos, com possibilidade de melhoria do peso medio final em $2,3 \%$ e da conversao al imentar total em $2,2 \%$, superam as desvantagens na tomada de decisao quanto ao uso de raçăo nas formas granulada e triturada.

\subsection{Granulometria do Milho}

Ds resultados de peso medio, ganho de peso medio e conversao alimentar das aves se encontram nas tabelas $31,32,33,34,35$ e 36. 
Tabela 31 . Peso médio das aves segundo o fator granulometria do milho $(7,14$ e 21 dias).

\begin{tabular}{cccc}
\hline $\begin{array}{c}\text { Granulometria } \\
\text { do milho }(\mathrm{mm})\end{array}$ & 7 & \multicolumn{2}{c}{ Idade(dias) } \\
& & 14 & 21 \\
\hline 4 & $133,99 \mathrm{a}$ & $329,81 \mathrm{a}$ & $644,75 \mathrm{a}$ \\
8 & $133,33 \mathrm{a}$ & $327,40 \mathrm{a}$ & $640,71 \mathrm{a}$ \\
12 & $128,50 \mathrm{~b}$ & $313,25 \mathrm{~b}$ & $616,39 \mathrm{~b}$
\end{tabular}

As medias seguidas por letras distintas na mesma coluna diferem entre si ao nivel de $5 \%$.

Tabela 32. Peso médio das aves segundo a fator granumetria do milho (28, 35 e 42 dias).

\begin{tabular}{cccc}
\hline $\begin{array}{c}\text { Granulometria } \\
\text { do milto }(\mathrm{mm})\end{array}$ & 28 & \multicolumn{3}{c}{ Idade(dias) } \\
& & \multicolumn{3}{c}{35} & 42 \\
\hline 4 & $1048,75 a$ & $1496,77 a$ & $2007,51 \mathrm{a}$ \\
8 & $1045,74 a$ & $1484,43 a b$ & $1996,17 a$ \\
12 & $1023,60 \mathrm{~b}$ & $1466,09 \mathrm{~b}$ & $1992,04 \mathrm{a}$
\end{tabular}

As medias seguidas por letras distintas na mesma coluna diferem entre $s i$ ao nivel de $5 \%$. 
Tabela 33. Ganho de peso medio das aves segundo - fator granulometria do milho (primeira, segunda e terceira semanas de idade).

\begin{tabular}{cccc}
\hline \multicolumn{3}{c}{ Granulometria } & \multicolumn{3}{c}{ Semanas } \\
do milho $(\mathrm{mm})$ & 1 & 2 & 3 \\
\hline 4 & $90,60 a$ & $195,79 a$ & $314,97 \mathbf{a}$ \\
8 & $90,00 \mathbf{a}$ & $194,07 \mathbf{a}$ & $313,28 \mathbf{a}$ \\
12 & $84,73 b$ & $184,75 b$ & $303,14 b$
\end{tabular}

As medias seguidas por letras distintas na mesma
coluna diferem entre $s i$ a nivel de $5 \%$

Tabela 34. Ganho de peso médio das aves segundo - fator granulometria do milno (quarta,quinta e sexta semanas de idade).

\begin{tabular}{|c|c|c|c|}
\hline \multirow{2}{*}{$\begin{array}{l}\text { Granulometria } \\
\text { do milho (mm) }\end{array}$} & \multicolumn{3}{|c|}{ Semanas } \\
\hline & 4 & 5 & 6 \\
\hline 4 & $403,97 a$ & $448,05 a$ & $510,74 a$ \\
\hline$B$ & $405,06 a$ & $443,76 a$ & $511,40 \mathrm{a}$ \\
\hline 12 & $407,21 a$ & $442,49 a$ & $525,95 a$ \\
\hline
\end{tabular}

As medias seguidas por letras distintas na mesma coluna diferem entre $5 i$ ao nivel de $5 \%$. 
Tabela 35. Conversao alimentar das aves segundo

- fator granulometria do milno $(1-7,1-14$

e 1 - 21 dias).

\begin{tabular}{cccc}
\hline \multirow{2}{*}{$\begin{array}{c}\text { Granulometria } \\
\text { do milho }(\mathrm{mm})\end{array}$} & $1-7$ & \multicolumn{2}{c}{ Periodos(dias) } \\
& & $1-14$ & $1-21$ \\
\hline 4 & $1,290 \mathrm{a}$ & $1,547 \mathrm{a}$ & $1,674 \mathrm{a}$ \\
8 & $1,243 \mathrm{~b}$ & $1,493 \mathrm{~b}$ & $1,646 \mathrm{a}$ \\
12 & $1,262 \mathrm{ab}$ & $1,540 \mathrm{ab}$ & $1,666 \mathrm{a}$ \\
\hline
\end{tabular}

As medias seguidas por letras distintas na mesma coluna diferem entre $5 i$ ao nivel de $5 \%$.

Tabela 36. Conversá alimentar das aves segundo

- fator granulometria do milho $(1-29,1-35$

e 1 - 42 dias).

\begin{tabular}{cccc}
\hline $\begin{array}{c}\text { Granulometria } \\
\text { do milho }(\mathrm{mm})\end{array}$ & $1-28$ & \multicolumn{2}{c}{ Periodos(dias) } \\
& & $1-35$ & $1-42$ \\
\hline 4 & $1,817 a$ & $1,971 a$ & $2,084 a$ \\
8 & $1,788 a$ & $1,934 b$ & $2,041 b$ \\
12 & $1,797 a$ & $1,948 b$ & $2,064 a b$
\end{tabular}

As medias seguidas por letras distintas na mesma coluna diferem entre $s i$ ao nivel de $5 \%$.

A granulometria do milho é um fator discutivel, nåo só quanto ao desempenho das aves em diferentes granulometrias, como aos tipos de moinhos utilizados na reduça do tamanho das particulas do alimento e seu consumo de energia eletrica.

Tradicionalmente os alimentos na indústria avicola são moidos do mesmo tamanho para que năo haja 
segregaço das particulas por parte das aves. Estas possuem alta capacidade de selecionar os granulos. Além disso, existe a dificuldade de se conseguir uma mistura homogênea com alimentos moidos de tamanho desuniforme. Estes problemas podem ser contornados com o uso da dieta nas formas triturada e granulada. Deste modo surgem dois fatores a serem observados : o primeiro, se há necessidade de se usar a raçao nas formas triturada e granulada, quando nao se moe de maneira uniforme os alimentos $e$ segundo se a utilizaçăo de granulometria grosseira irá afetar o desempentio das aves a a qualidade do grânulo.

A interaçå forma de raçăo e granulometria do milho nao foi significativa para os indices de desempenho analisados, a que permitiu concluir que nao há necessidade de se utilizar as formas triturada e granulada para mascarar a moagem grosseira do milho.

observa-se nas tabelas $31,32,33$ e 34 que a granulometria de $12,0 \mathrm{~mm}$. constituiu problema pois prejudicou o peso médio até 35 dias de idade e o ganho de peso ate a terceira semana de idade, devido a dificuldade das aves em se alimentarem no periodo inicial com uma raçă de granulometria grosseira. No final do experimento as aves recuperaram o peso, sendo que aos 42 dias de idade as diferenças significativas desapareceram.

BERG \& BEARSE (1944), trabalharam com raçoes que variavam de uma granulometria grosseira á fina e obtiveram melhores resultados com o uso de uma granulometria grosseira. ELEY \& HOFFMANN (1949), moeram o milho utilizando uma peneira com crivo de $1 / 2$ polegada, escolhida apds testes que determinaram que a grao inteiro nao passava neste crivo. As granulometrias comparadas foram $1 / 2$ polegada, $1 / 4$ e 2/32 de polegadas, e estas nao tiveram efeito sobre o consumo de alimento e água, nem sobre o ganho de peso. As aves alimentadas com raçà de 
granulometria mais grosseira ( $1 / 2$ polegada) estiveram mais pesadas que as outras.

DAVIS et alii (1952), trabalharam com granulometrias do milho e observaram que no inicio as aves preferem particulas menos grosseiras, e após este periodo passaram a selecionar as mais grosseiras.

REECE et alii (1986a), trabalharam com duas granulometrias do milho 4,76 e $6,35 \mathrm{~mm}$. fornecidas na raça na forma triturada (inicial e final) e triturada-granulada (inicial-final). Houve uma tendencia das aves alimentadas com a granulometria mais grosseira na forma triturada apresentarem melhor desempenho. A diferença entre o desempenho das aves alimentadas com as duas granulometria foi minima. O rendimento do moinho melhorou em $27 \%$ com a substituiçao da granulometria de 4,76 para $6,35 \mathrm{~mm}$. e a reduçào no consumo de energia foi cerca de $35 \%$.

REECE et alii (1986b), utilizaram o milho moido variando de 3,18 a $9,53 \mathrm{~mm} .$, e observaram que os melhores resultados foram obtidos com as granulometrias de 3,18 e $9,53 \mathrm{~mm}$. comparada a $6,35 \mathrm{~mm}$.. Os granulos onde - milho utilizado foi o de $9,35 \mathrm{~mm}$. foram significativamente mais resistentes $(P<O, O 5)$ do que os grânulos que utilizaram granulometria fina, a que contraria o pensamento comum entre os pesquisadores de que os alimentos devam ser moidos uniformemente para que o grânulo apresente melhor textura.

BUTOLD et alli (1987) trabalharam com diferentes granulometrias no periodo de 1 a 28 dias de idade das aves $(2,0,3,0,4,0,6,0$ e $8,0 \mathrm{~mm}$.$) e nao$ encontraram diferencas significativas (P>0,05) quanto ao ganho de peso, consumo de raçăo e conversão alimentar. observa-se nas tabelas 35 e 36 que a conversaes alimentares das granulometrias 8,0 e $12,0 \mathrm{~mm}$. foram numericamente melhores em todos os periodos anali- 
sados. Os resultados obtidos permitiram concluir que o uso de granulometria mais grosseira, nao afetou o desempenho das aves, sendo que em alguns casos apresentou melhora, além de representar considerável economia de energia e aumento no rendimento industrial da moagem. 
5. CONCLUSÕES

Com base nos resultados obteve-se as seguintes conclusbes:

- A forma de raça e a granulometria do milho apresentaram efeitos distintos no desempenho de frangos de corte.

- A moagem grosseira do milho ná foi mascarada pelo uso da raça nas formas granulada ou triturada.

- A forma de raçao triturada determinou melhor desempenho das aves em relaçăo as alimentadas com raçăo farelada. 0 peso medio destas aos 42 dias foi $2,32 \%$ maior que das que receberam raçăo farelada, bem como a conversăo alimentar, que foi $2,2 \%$ melhor com o uso de raço triturada.

- A granulometria mais grosseira pode ser utilizada deste o primeiro dia de idade sem que o desempenho final dos frangos de corte seja afetado. Nao houve diferença no peso final entre as três granulometrias e a que determinou melhor conversăo alimentar no periodo de 1 a 42 dias de idade foi a de $8,0 \mathrm{~mm}$ seguida pela de $12,0 \mathrm{~mm}$ e finalmente a de $4,0 \mathrm{~mm}(2,041 \mathrm{vs} .2,064 \mathrm{vs} .2,084)$, sugerindo que a diferença significativa $(P<0,05)$ quanto ao ganho de peso nas três primeiras semanas e no peso medio até 35 dias sofreu um ganho compensatório a medida que as aves cresceram, desaparecendo o efeito da granulometria grosseira na fase final da criaça. 


\section{REFERENCIAS BIBLIQGRÁFICAS}

ALLRED, J.B.; JENSEN, L.S.; MEGINNIS, J. Studies on the growth. promoting effects induced by pelleting feed. Poultry Science, Champaign, 35: 1130,1956 .

ALLRED, J.B.; JENSEN, L.S.; MCGINNIS, J. Factors affecting the response of chicks and poults to feed pelleting. Poultry Science, Champaign, 36: $517-23,1957 a$.

ALLRED, J.B.; FRY, R.E.; JENSEN, L.S.; MCGINNIS, J. Studies with chicks on improvement in nutritive value of feed ingredients by pelieting. Poultry Science, Champaign, 36: 1284-9, 1957b.

AUCKLAND, J.N. \& FULTON, R.B. Effect of energy concentration on the response to pelleting in broiler diets. World Poultry Science, London, 27(2): 162, Apr/Jun. 1971.

AUCKLAND, J.N. \& FULTON, R.B. The effects of dietary nutrient concentration, crumbles versus mash and age of dam on the growth of broiler chicks. Poultry Science, Champaign, 51: $1968-75,1972$. 
BAYLEY, H.S.; SUMMERS, J.D.; SLINGER, S.J. The effect of steam pelleting feed ingredients on chick perfomance: effect on phosphorus availability, metabolizable energy value and carcass composition. Poultry Science, Champaign, $47(1): 1140-8,1968 \mathrm{a}$.

BAYLEY, H.S.; SLINGER, S.J.; AITKEN, J.R.; BIELY, B.R.; CLAUDININ, D.R.; NEIL, J.B.O.;ROBBLEE, A.R.; SELL, J.L. The influence of method of crumbling diets containing different levels of protein and lysine on chick perfomance. Poultry Science, Champaign, 47(1): 677-85, $1968 \mathrm{~b}$.

BEARSE, G.E.; BERG, L.R.;MCCLARY,C.F.; MILLER, V.L. The effect on chick growth and feed eficiency of pelleting rations of diferent fiber levels. Poultry Science, Champaign, 31 (5): 907, Sept. 1952 .

BERG,L.R. \& BEARSE, G.E. The effect of size and shape of feed particles on the development of growing poults. Poultry Science, Champaign, $\underline{26}(5)$ : 532, Sept. 1947 .

BERTECHINNI, A.G. Efeitos de programas de alimentaçăo, nivel de energia, forma fisica da recaro e temperatura ambiente sobre o desempenho e custo por unidade de ganho de peso em frangos de corte. Viçosa, 1987. 204 p. (Doutorado - Universidade Federal de Viçosa). 
BOLTON, W. The digestibility of mash and pellets by chick. Journal of Agricultural Science, Cambridge, 55(1): 141-2, 1960.

BRUE,R.N. \& LATSHAW, J.D. Growth and energy retention of broilers as affected by pelleting and by density of the feed. Poultry Science, Champaign, so( 7 ): 1630, July. 1981.

BUTOLO, J.E.; ARIKI, J.; PINTO, R.A.; MARUJO, V.M.; CURTARELLI, $S$. Efeitos causados pela granulometria inadequada em milho para raçôs de frango de corte. In: CONGRESSO BRASILEIRO DE AVICULTURA, 10., Natal, 1987. Anais. Natal, Associaça Riograndense de Avicultura, 1987. p.93-4.

CHOI, J.H.; SO, B.S.; RYU, K.S.; LANG, S.L. Effects of pelleted on crumble diets on theperfomance and the devlopment of the digestive organs of broilers. Poultry Science, Champaign, 65(3): 594-7, Mar. 1986.

DALE, N.M. \& FULLER,H.L. Effect of low temperature, diet density, and pelleting on the preference of broilers of high fat rations. Poultry Science, Champaign, 5e(5): 1337-9, Sept. 1979 .

DAVIS, R.L.; BRIGS, G.M.; SLOAN, H.J. The modulus of ground corn in a corn soybean oilmeal chick starting ration. Poultry Science,

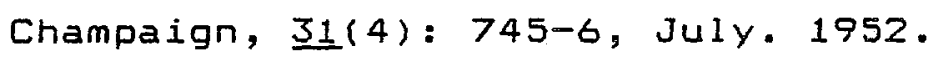


DEATON, J.W.; LOTT, B.D.; MAY, J.D. Effect of

beak trimming on body weight and feed intake of broiler roasters fed pellet or mash. Poultry Science, Champaign, $\underline{\text { 6g( }}$ (10): 1342-4, Oct. 1988.

DEATON, J.W.; LOTT, B.D.; SIMMONS, J.D. Hammer mill versus roller mill grinding of corn for commercial egg layers. Poultry science, Champaign, 68(10): 1342-4, oct. 1989 .

DEATON, J.W.; MAY, J.D.; LOTT, B.D. Weight gain of summer-reared egg-type pullets fed pellets versus mash. Poultry Science, Champaign, $67(3): 375-7$, Mar. 1987.

ELEY, C.D. \& BELL, J.C. Particle size of broiler feed as a factor in the consumption and excretion of water. Poultry Science, Champaign, 27(5): 660-1, Sept. 1948 .

ELEY, C.D. \& HOFFMANN, E. Feed particle size as a factor in water consumption and elimination. Poultry Science, Champaign, 28(2): 215-22, Mar. 1949.

FEEDING pellets or crumbles to broilers. Poultry International, Illinois, 28(5): 96-8, May. 1989.

HEYWANG, B.W. \& MORGAN, R.B. A comparision of a pelleted and unpelleted all mash diet for growing chickens. Poultry Science, Champaign, $\underline{23}(1): 16-20$, Jan. 1944 . 
HINDS, F.C. \& SCOTT, H.M. Age of chick - a factor in the response to pelleted corn. Poultry Science, Champaign, 37: 189-92, 1958.

HULAN, W.H. \& PROUDFOOT, F.G. Effect of dibasic calcium phosphate (ad $l i b i t u m$ ) and feed texture on the general perfomance and incidence of leg abnormalities of roaster chickens. Canadian Journal Animal Science, Alberta, $67(1):$ 103-12, Mar. 1987.

HUSSAR, N. \& ROBBLEE, A.R. Effects of pelleting on the utilization of feed by the growing chicken. Poultry Science, Champaign, $\underline{41}=1489-93,1962$.

JENSEN, L.S. Pelleting research at Washington State college. Feedstuffs, Minnentoka, $\underline{60}(17): 18-20,1956$.

JENSEN, L.S:; MERRILL, L.H.; REDDY, C.V.; MEGINNIS, J. Observations on eating patterns and rate of food passage of birds fed pelleted and unpelieted diets. Poultry Science, Champaign, 41: $1414-9,1962$.

JONES, F.T. Pelleting... Is it worth it? Poultry Digest, New Jersey, $38(450)$ : 454-6, Aug. 1979.

LANSON, R.K. \& SMYTH, J.R. Pellets vs. mash plus pellets vs. mash for broiler feeding. Poultry Science, Champaign, 34: 234-5, 1955. 
LOWE,R.H. Are we mixing feed as we should?

Poultry International, Illinois, $24(6)$, Jun. 1985.

MCINTOSH, J.I . ; SLINGER, S.J .; SIBBALD, I.R.; ASHTON, G.C. Factors affecting the metabolizable energy content of poultry feeds. Poultry Science, Champaign, 41: 445-56, 1962.

McNAUGHTON, J,L. Effect of feed texture on broilers perfomance. Poultry Diqest, New Jersey, $43(508): 254-5$, Jun. 1984.

MCNAUGHTON, J.L. \& REECE, F.N. Factors affecting pelleting response 1 . Influence of dietary energy in broiler starter diets. Poultry Science, Champaign, $\underline{\underline{3}}(4)$ : 682-5, Apr. 1984.

MILOSEVIC, N.; PAVLOVSKI, Z.; MASIC, B. Effect of pelleted diet on productivity of broilers. Peradarstvo, Belgrade, 21(4): 21-3, 1986. Apud Nutrition Abstracts and Reviews. (Ser.B) Wallingford, $56(6)$ :850, Dec. 1986. (Resumo).

MOKHAMED, A. Kh. Effect of the energy level and pelleting of mixed feeds on the productivity of broiler chickens. Zhivotnov" dni Nauki, Kostinbrod, $\underline{22}(9): 47-53,1985$. Apud $\underline{\mathrm{Nu}}$ trition Abstracts and Reviews. (Ser. B), Wa11 ingford, 56 (6): 396, Jun. 1986. (Resuma). 
PEPPER, W.F.; SLINGER, S.J.; SUMMERS, J.D. Studies with chickens and turkeys on the relationship between fat, unidentified factors and pelleting. Poultry Science, Champaign, 39(1): $66-74,1960$.

PFOST, H.B. Basic processing operations. In : SWINEHART, C.E. \& PFOST, H.B., ed. Feed manufacturing technology, Illinois, American Feed Manufacturers Association, 1970, cap.3, P. $73-7$.

PLAVNIK, I. \& HURWITZ, S. Effect of dietary protein, energy, and feed pelleting on the response of chicks to early feed restriction. Poultry Science, Champaign, $\underline{1}(8)$ : 1118-25, Aug. 1989.

PORTELA, F.J. Feed particle size affects intake. Poultry Digest, New Jersey, 48(567): 237, May. 1989.

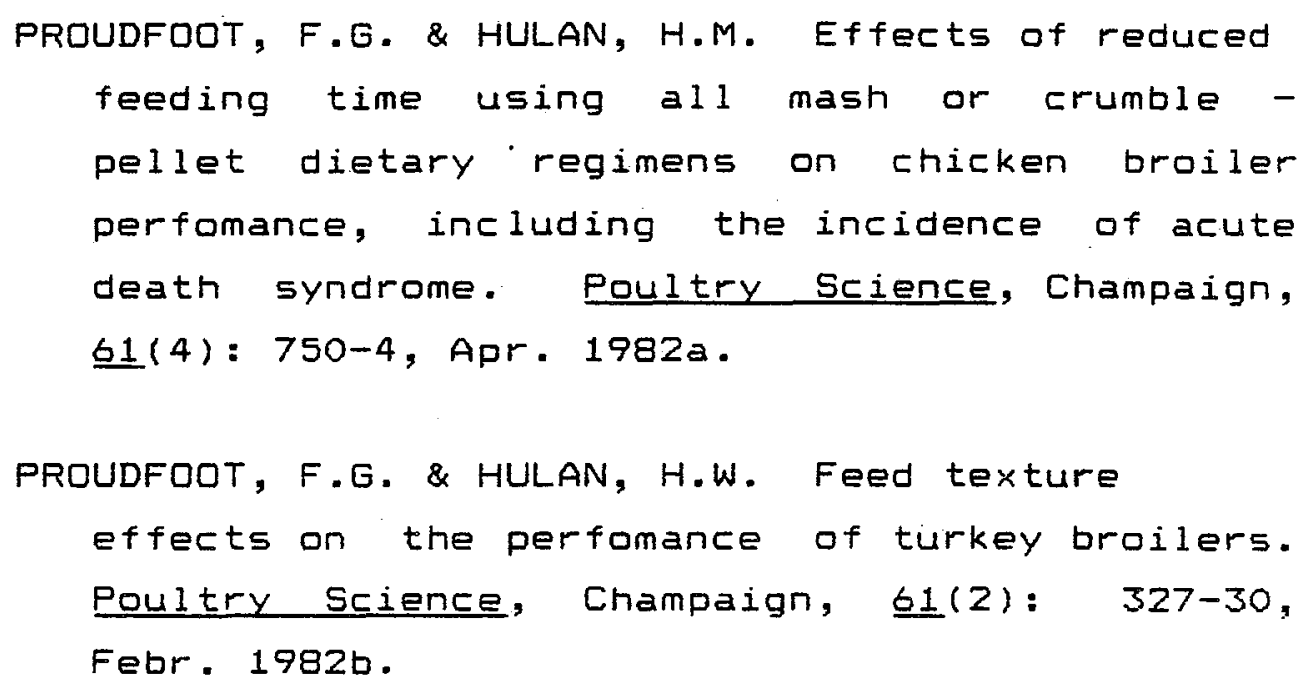

PROUDFOOT, F.G. \& HULAN, H.W. Feed texture effects on the perfomance of turkey broilers. Poultry Science, Champaign, 盀(2): 327-30, Febr. 1982b. 
PRQUDFOOT, F.G. \& HULAN, H.W. Feed texture

effects on the perfomance of roasters chickens. Canadian Journal Animal Science, Alberta, 699(3): 801-7, Sept. 1989 .

PROUDFOOT, F.G. \& SEFTON, A.E. Feed texture and light treatment effects on the perfomance of chicken broilers. Poultry Science, Champaign, 57(2): 408-16, Mar. 1978 .

PROUDFOOT, F.G.; HULAN, H.W.; MCRAE, K.B. The effects of crumbled and pelleted feed on the incidence of sudden death syndrome among male chicken broilers. Poultry Science, Champaign, $\underline{61}(8): 1766-8$, Aug. 1982 .

PROUdFQOT, F.G.; HULAN, H.W.; MCRAE, K.B. The effects of dietary micronutrient, fat and protein components in pelleted feeds on the incidence of sudden death syndrome and other traits among male broiler chickens. Canadian Journal Animal Science, Alberta, b4(1): 15964, Mar. 1984. 
REDDY, C.V.; JENSEN, L.S.; MERILL, L.H.; MCGINNIS,J. Influence of mechanical alteration of dietary density on energy available for chick growth. Journal of Nutrition, Philadelfia, 777(4): 428-32, Aug. 1962 .

REECE, F.N. \& LOTT, B.D. Roller mills found competitive in broiler feed production. Feedstuffs, Minnentoka, $\underline{\text { 77 }}(48):$ E1-E2, Nov. 1985.

REECE, F.N.; LOTT, B.D.; DEATON, J.W. The effects of feed form, protein profile, energy level, and gender on broiler perfomance in warm (26,7 C) environment. Poultry Seience, Champaign, 63(10): 1906-11, act. 1984 .

REECE, F.N.; LOTT, B.D.; DEATON, J.W. The effects of feed form, grinding method, energy level, and gender on broiler perfomance in a moderate (21,0 C) environment. Poultry Scien드, Champaign, 64(10): 1834-9, 0ct. 1985.

REECE, F.N.; LOTT, B.D.; DEATON, J.W. Effects on environmental temperature and corn particle size on response of broilers to pelleted feed. Poultry Science, Champaign, $65(4):$ 636-41, Apr. 1986a.

REECE, F.N.; LOTT, B.D.; DEATON, J.W. The effects of hammer mill screen size on ground corn particle size, pellet durability, and broiler perfomance. Poultry Science, Champaign, 65(7): 1257-61, Jul. 1986b. 
REECE, F.N.; LOTT, B.D.; DEATON, J.W. Meal feeding and broiler perfomance. Poultry Science, Champaign, 65(8): 1497-501, Aug. 1986c.

RUNNELS, T.D.; MALONNE, G.W.; KLOPP, S. The influence of feed texture on broiler performance. Poultry Science, Champaign, 55(5): 1958-61, Sept. 1976.

SIBBALD, I.R. The effect of steam pelleting on the true metabolizable energy values of poultry diets. Poultry Science, Champaign, 56 (5): 1686-8, Sept. 1977 .

SILVA, J. M.L. da; DALE, N.; LUCHESI, J.B. Effect of pelleted feed on the incidence of ascites in broilers reared at low altitudes. Avian Diseases, Kennett Square, 32: 376-8, 1988 .

SOUZA, J.L.G.; MENDES, A.A.; MORITA, M.; PARRE, C.; MILTEMBurg, G. Desempenho de frangos de corte alimentados com raços fareladas e granuladas. In: REUNIÁO ANUAL DA SOCIEDADE BRAZILEIRA DE ZOOTECNIA, 24., Piracicaba, 1982. Anais, Piracicaba, Sociedade Brasileira de Zooternia, 1982. p.37-8.

STEWART, W.I. \& UPP, C.W. The effect of form of feed on growth and feed eficiency, pellet versus mash versus granules for broilers. Poultry Science, Champaign, 30(1): 63-6, Jan. 1951 . 
SUTTON, C. Pelleting of feed offer oportunities calls for decisions. Poultry Science, Champaign, 42(500): 502-3, Oct. 1983 .

WENK, C. \& ES, A.J.H. Van. Feed as pellets or as meal for growing chickens. Archiv für Geflügelkunde, Zürich, 43(5): 210-4, 1979. Apud Nutrition Abstracts and Reviews. (Ser. B), Wallingford, 50(11): 614, Nov. 1980 . (Resumo).

WILSON, H.R. \& NESBETH, W.G. Pellets versus mash for starting Bobwhite quail. Poultry Science, Champaign, $\underline{59}(4)=932-4$, Apr. 1980.

ZELENKA, J. \& SIROKY, M. Pelleted mill for fattening broilers. Acta Universitatis Agriculturae Brno, Brno, $\underline{27}(1): 163-8,1979$. Apud Nutrition Abstracts and Reviews. (Ser. B); Wallingford, $\underline{51}(2): 111$, Feb. 1981. (Resumo). 
Apêndice 1. Temperaturas minimas e máximas registradas durante o periodo experimental.

Lado NE Lado SW

Data

03.06 .89

04.06 .89

05.06 .89

06.06 .89

07.06 .89

08.06 .89

09.06 .89

10.06 .89

11.06 .89

12.06 .89

13.06 .89

14.06 .89

15.06 .89

16.06 .89

17.06 .89

18.06 .89

19.06 .89

20.06 .89

21.06 .89

22.06 .89

23.06 .89

24.06 .89

25.06 .89

26.06 .89

27.06 .89

28.06 .89

29.06 .89

30.06 .89

01.07 .89

02.07 .89

03.07 .89

\begin{abstract}
Minimas
\end{abstract}
21

18

16

16

18

20

18

18

18

15

14

11

11

14

14

14

14

15

14

16

14

15

18

16

14

14

12

11

13

17

18
Máximas

30

31

31

30

31

33

28

29

27

28

25

26

26

26

23

26

26

27

26

27

29

31

27

23

26

26

20

25

26

28

33
Minimas

17

16

16

15

16

19

16

17

16

13

13

11

10

12

13

14

14

14

12

14

14

15

16

15

14

14

12

12

13

16

18
Máximas

26

29

27

26

28

29

26

27

26

27

21

22

22

22

21

24

26

26

24

24

24

28

26

22

22

24

20

24

24

27

29 


$\begin{array}{lllll}\text { (continuaçđo) } & & & & \\ 04.07 .89 & 14 & 26 & 15 & 24 \\ 05.07 .89 & 19 & 31 & 17 & 28 \\ 06.07 .89 & 15 & 30 & 15 & 22 \\ 07.07 .89 & 11 & 17 & 12 & 16 \\ 08.07 .89 & 14 & 22 & 13 & 20 \\ 09.07 .89 & 10 & 23 & 09 & 21 \\ 10.07 .89 & 10 & 24 & 09 & 22 \\ 11.07 .89 & 10 & 25 & 10 & 22 \\ 12.07 .89 & 10 & 25 & 12 & 21 \\ 13.07 .89 & 10 & 26 & 10 & 22\end{array}$


Apêndice 2. Peso semanal medio por parcela nos

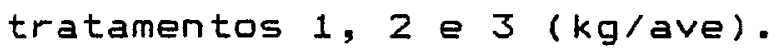

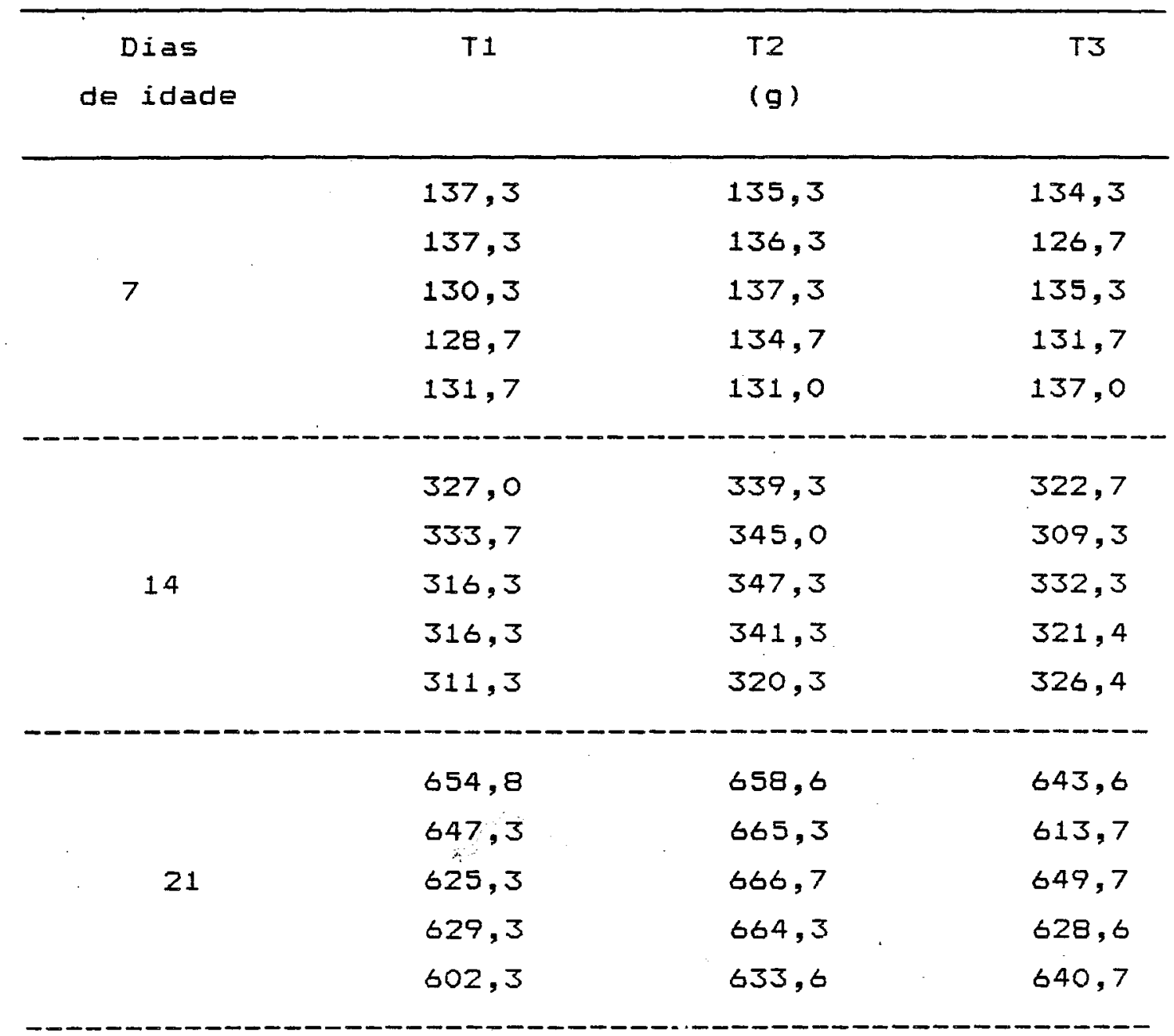


(continuaça)

\begin{tabular}{|c|c|c|c|}
\hline \multirow{5}{*}{28} & 1033,4 & 1090,7 & 1051,8 \\
\hline & 1061,7 & 1085,7 & 1043,1 \\
\hline & 1007,9 & 1063,8 & 1062,3 \\
\hline & 1034,5 & 1069,0 & 1023,1 \\
\hline & 1002,6 & 1038,2 & 1046,5 \\
\hline \multirow{5}{*}{35} & 1448,3 & 1521,9 & 1477,5 \\
\hline & 1492,5 & 1510,0 & 1478,3 \\
\hline & 1479,6 & 1538,6 & 1502,3 \\
\hline & 1464,5 & 1547,6 & 1478,3 \\
\hline & 1470,4 & 1494,4 & 1472,4 \\
\hline \multirow{5}{*}{42} & 1951,0 & 2014,6 & 1996,4 \\
\hline & 1992,1 & 2062,6 & 1979,3 \\
\hline & 2007,4 & 2046,4 & 1993,0 \\
\hline & 1948,3 & 2093,1 & 1992,4 \\
\hline & 1923,2 & 2036,3 & 1986,2 \\
\hline
\end{tabular}


Apêndice 3. Peso semanal médio por parcela nos tratamentos 3,4 e 5 ( $k g / a v e)$.

\begin{tabular}{|c|c|c|c|}
\hline $\begin{array}{c}\text { Dias } \\
\text { de idade }\end{array}$ & T3 & $\begin{array}{l}\text { T4 } \\
(g)\end{array}$ & T5 \\
\hline \multirow{5}{*}{7} & 137,0 & 130,3 & 134,0 \\
\hline & 132,3 & 119,3 & 127,7 \\
\hline & 134,0 & 132,3 & 128,7 \\
\hline & 132,7 & 131,0 & 133,3 \\
\hline & 132,3 & 118,7 & 129,7 \\
\hline \multirow{5}{*}{14} & 345,3 & 318,9 & 329,0 \\
\hline & 328,9 & 303,0 & 314,5 \\
\hline & 329,3 & 321,7 & 313,7 \\
\hline & 334,3 & 315,0 & 316,7 \\
\hline & 324,0 & 293,0 & 307,0 \\
\hline \multirow{5}{*}{21} & 668,6 & 612,1 & 631,7 \\
\hline & 636,2 & 600,7 & 627,2 \\
\hline & 641,0 & 623,7 & 628,0 \\
\hline & 651,3 & 623,8 & 622,0 \\
\hline & 633,7 & 584,7 & 610,0 \\
\hline
\end{tabular}


(continuaçào)

\begin{tabular}{cccc}
1063,8 & 1000,0 & 1060,3 \\
1032,7 & 1013,2 & 1027,6 \\
1025,7 & 1032,7 & 1048,3 \\
& 1071,7 & 1044,6 & 1010,3 \\
1036,7 & 992,3 & 1006,7 \\
35 & 1514,3 & 1445,2 & 1486,2 \\
& 1457,8 & 1437,0 & 1512,7 \\
& 1502,4 & 1474,8 & 1509,2 \\
& 1492,0 & 1466,8 & 1487,3 \\
& 1469,0 & 1420,0 & 1421,7 \\
42 & 2017,1 & 1972,8 & 1988,6 \\
& 1962,2 & 1969,6 & 2044,8 \\
2013,8 & 1986,2 & 2060,7 \\
& 2039,3 & 2010,0 & 2024,0 \\
& 1982,0 & 1926,7 & 1937,0 \\
\hline
\end{tabular}


Apêndice 4. Consumo semanal total de raçăo por parcela nos tratamentos 1,2 e 3 . (kg/parcela)

\begin{tabular}{|c|c|c|c|}
\hline Semanas & $T 1$ & $\begin{array}{c}\mathrm{T} 2 \\
(\mathrm{~kg})\end{array}$ & T3 \\
\hline \multirow{5}{*}{1} & 3,55 & 3,31 & 3,50 \\
\hline & 3,61 & 3,53 & 3,23 \\
\hline & 3,53 & 3,70 & 3,47 \\
\hline & 3,45 & 3,63 & 3,28 \\
\hline & 3,39 & 3,35 & 3,38 \\
\hline \multirow{5}{*}{2} & 10,09 & 8,8 & 9,27 \\
\hline & 9,68 & 10,32 & 9,06 \\
\hline & 10,36 & 9,89 & 9,88 \\
\hline & 9,72 & 9,79 & 9,25 \\
\hline & 9,64 & 9,17 & 9,54 \\
\hline \multirow{5}{*}{3} & 16,94 & 16,90 & 16,23 \\
\hline & 16,87 & 16,81 & 16,66 \\
\hline & 16,71 & 16,94 & 16,96 \\
\hline & 16,20 & 17,36 & 16,37 \\
\hline & 16,24 & 16,34 & 16,19 \\
\hline
\end{tabular}


(continuaçå)

\begin{tabular}{|c|c|c|c|}
\hline & 23,62 & 22,10 & 23,03 \\
\hline & 24,60 & 24,92 & 23,29 \\
\hline \multirow[t]{3}{*}{4} & 23,81 & 24,20 & 24,28 \\
\hline & 23,38 & 24,58 & 23,59 \\
\hline & 22,73 & 22,79 & 23,57 \\
\hline \multirow{5}{*}{5} & 28,11 & 27,13 & 27,70 \\
\hline & 29,45 & 30,33 & 30,03 \\
\hline & 30,37 & 30,25 & 30,14 \\
\hline & 30,15 & 32,54 & 27,56 \\
\hline & 27,77 & 29,79 & 29,11 \\
\hline \multirow{5}{*}{6} & 35,61 & 31,52 & 32,00 \\
\hline & 34,07 & 36,47 & 36,19 \\
\hline & 34,69 & 35,73 & 34,61 \\
\hline & 33,12 & 37,31 & 37,62 \\
\hline & 30,13 & 34,14 & 33,05 \\
\hline
\end{tabular}


Apêndice 5. Consumo semanal total de raçao por parcela nos tratamentos 4,5 e 6. (kg/parcela)

\begin{tabular}{|c|c|c|c|}
\hline Semanas & $T 4$ & $\begin{array}{l}\text { Ts } \\
(\mathrm{kg})\end{array}$ & T6 \\
\hline \multirow{5}{*}{1} & 3,53 & 3,23 & 3,47 \\
\hline & 3,22 & 2,95 & 3,30 \\
\hline & 3,35 & 3,35 & 3,11 \\
\hline & 3,27 & 3,33 & 3,20 \\
\hline & 3,33 & 2,92 & 3,21 \\
\hline \multirow{5}{*}{2} & 10,09 & 9,98 & 9,30 \\
\hline & 9,45 & 9,08 & 8,85 \\
\hline & 7,79 & 9,58 & 9,07 \\
\hline & 9,54 & 9,11 & 9,18 \\
\hline & 9,26 & 8,71 & 9,0 \\
\hline \multirow{5}{*}{3} & 16,57 & 10,70 & $16 ., 25$ \\
\hline & 15,60 & 16,07 & 15,52 \\
\hline & 18,51 & 17,05 & 16,44 \\
\hline & 16,68 & 16,41 & 16,26 \\
\hline & 16,48 & 16,04 & 16,03 \\
\hline
\end{tabular}


(continua̧̧a)

\begin{tabular}{cccc}
23,28 & 21,33 & 22,86 \\
21,74 & 22,52 & 23,22 \\
24,21 & 22,84 & 23,91 \\
24,12 & 23,51 & 22,85 \\
23,73 & 24,15 & 22,76 \\
& 27,53 & 25,51 & 31,06 \\
5 & 27,19 & 26,13 & 29,85 \\
& 29,84 & 29,69 & 28,29 \\
& 29,22 & 27,75 & 27,72 \\
30,19 & 29,73 & 28,42 \\
& 33,84 & 30,86 & 30,00 \\
& 30,58 & 33,06 & 35,93 \\
34,88 & 34,95 & 38,52 \\
& 33,56 & 39,70 & 32,84 \\
& 35,32 & 34,20 & 30,79 \\
\hline
\end{tabular}


Apêndice 6. Mortalidade e refugagem nos tratamentos $1,2,3,4,5$ e 6, número de ocorrência nas 5 repetiçoes.

\begin{tabular}{|c|c|c|c|c|c|c|c|c|c|c|c|}
\hline \multirow[t]{2}{*}{ Semana } & \multicolumn{2}{|c|}{$T_{1}$} & \multicolumn{2}{|c|}{$T 2$} & \multicolumn{2}{|c|}{ T3 } & \multicolumn{2}{|c|}{ T4 } & \multicolumn{2}{|c|}{ T5 } & T6 \\
\hline & $M$ & $R$ & $M$ & $\mathbf{R}$ & $M$ & $R$ & $M$ & $\mathrm{R}$ & $M$ & $\mathrm{R}$ & $M$ \\
\hline
\end{tabular}

\begin{tabular}{|c|c|c|c|c|c|c|c|c|c|c|c|c|}
\hline 1 & 1 & 0 & 2 & 0 & 1 & 0 & 1 & 0 & 4 & 0 & 0 & 0 \\
\hline 2 & 0 & 0 & 1 & 0 & 3 & 0 & 1 & 0 & 2 & 0 & 1 & 0 \\
\hline 3 & 1 & 0 & 2 & 0 & 0 & 0 & 1 & 0 & 2 & 1 & 0 & 1 \\
\hline 4 & 1 & 1 & 1 & 0 & 1 & 1 & 1 & 0 & 3 & 0 & 1 & 0 \\
\hline 5 & 1 & 3 & 0 & 2 & 0 & 0 & 2 & 0 & 2 & 1 & 2 & 1 \\
\hline 6 & 1 & 4 & 0 & 4 & 1 & 0 & 3 & 2 & 0 & 1 & 3 & 6 \\
\hline
\end{tabular}

M - mortalidade

$R$ - refugagem 